\title{
Duet-splitting and the evolution of gibbon songs
}

\section{THOMAS GEISSMANN*}

Institute of Zoology, Tierärztliche Hochschule Hannover, Germany and Anthropological Institute, University Zürich-Irchel, Switzerland

(Received 16 October 2000; revised 29 August 2001; accepted 7 September 2001)

\begin{abstract}
Unlike the great apes and most other primates, all species of gibbons are known to produce elaborate, speciesspecific and sex-specific patterns of vocalisation usually referred to as "songs". In most, but not all, species, mated pairs may characteristically combine their songs in a relatively rigid pattern to produce coordinated duet songs. Previous studies disagree on whether duetting or the absence of duetting represented the primitive condition in gibbons. The present study compares singing behaviour in all gibbon species. Various vocal characteristics were subjected to a phylogenetic analysis using previously published phylogenetic trees of the gibbon radiation as a framework. Variables included the degree of sex-specificity of the vocal repertoire, the occurrence of solo songs, and the preference for a specific time of day for song-production. The results suggest the following scenario for the evolution of gibbon songs: (1) The last common ancestor of recent gibbons produced duet songs. (2) Gibbon duets probably evolved from a song which was common to both sexes and which only later became separated into male-specific and female-specific parts (song-splitting theory). (3) A process tentatively called "duet-splitting" is suggested to have led secondarily from a duetting species to a non-duetting species, in that the contributions of the pair-partners split into temporally segregated solo songs. This appears to be the first time that a non-duetting animal can be shown to be derived from a duetting form. (4) The return to exclusive solo singing may be related to the isolated island distribution of the non-duetting species.
\end{abstract}

Key words: Hylobatidae, gibbon, song, duet, call, vocalisation, evolution, Hylobates, Nomascus, Symphalangus, Bunopithecus.

\section{CONTENTS}

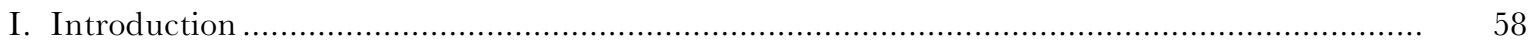

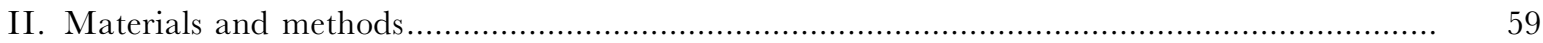

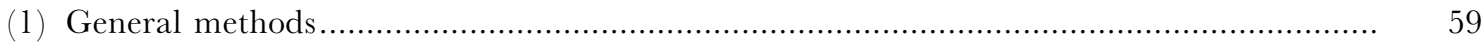

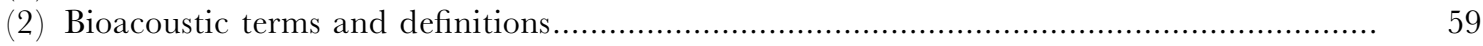

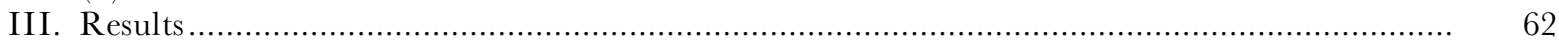

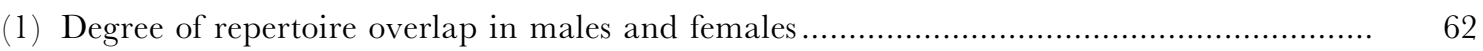

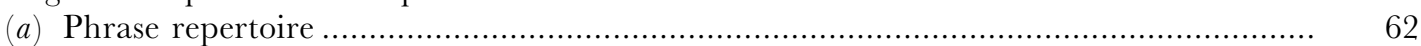

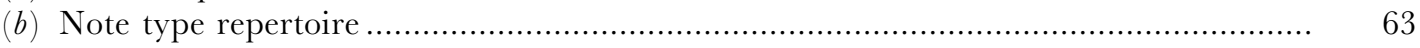

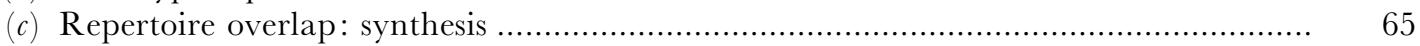

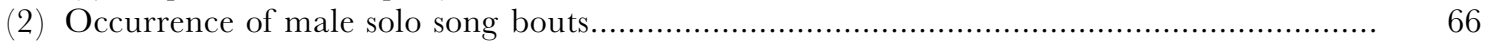

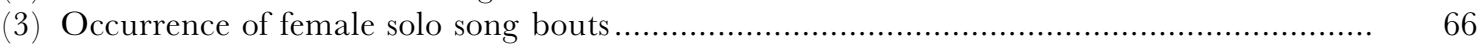

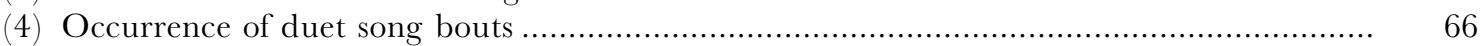

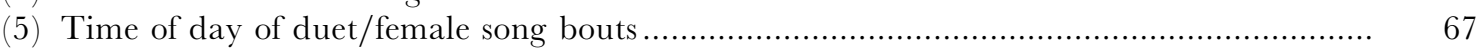

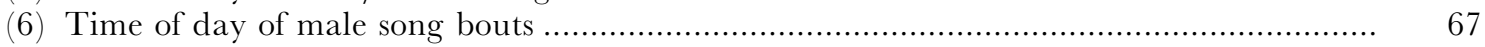

* E-mail: thomas.geissmann@tiho-hannover.de 


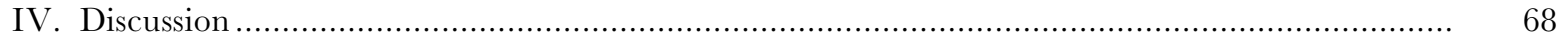

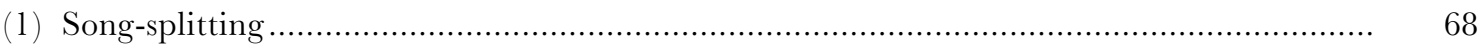

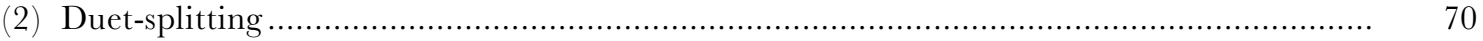

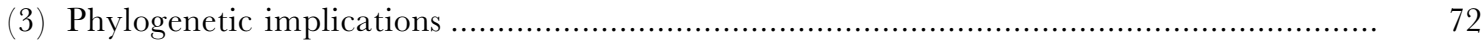

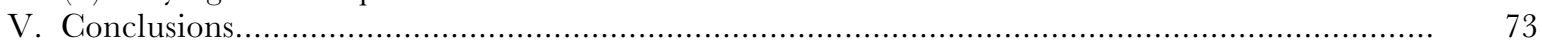

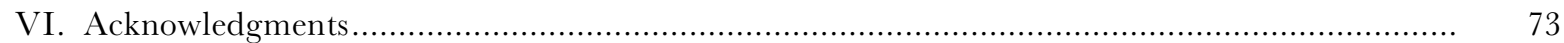

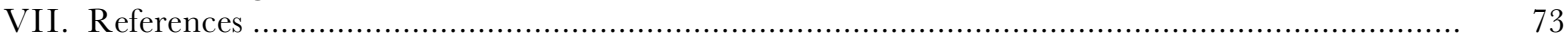

\section{INTRODUGTION}

Although duet songs are known for many species of birds and several species of primates (e.g. Farabaugh, 1982; Geissmann, 2000b; Haimoff, 1986; Thorpe, 1961, 1972), previous studies have mainly been interested in analysing the structure, variability, context, systematical relevance and functional significance of duet songs. The evolution of duet songs has only rarely been studied (Geissmann, 1993, 2000b; Wickler \& Seibt, 1982). Duet singing appears to occur mainly in monogamous species living in dense tropical forests (Thorpe, 1972) and evolved several times independently, probably four times in primates alone (Geissmann, 2000b). A comparative survey of, and attempts to reconstruct the essential stages which occurred during the evolution of, duet songs in gibbons or lesser apes (Hylobatidae) is presented here.

Gibbons are distributed throughout the tropical rain forests of South-east Asia (Chivers, 1977; Geissmann, 1995a; Marshall \& Sugardjito, 1986) and live in monogamous, territorial family groups (Brockelman \& Srikosamatara, 1984; Chivers, 1984; Leighton, 1987). All species of gibbons are known to produce elaborate, loud, long, stereotyped patterns of vocalisation often referred to as "songs" (Geissmann, 1993, 1995a; Haimoff, 1984a; Marshall \& Marshall, 1976). Songs are mainly uttered at specifically established times of day. In most species, mated pairs may characteristically combine their songs in a relatively rigid pattern to produce coordinated duet songs. Several functions have been attributed to gibbon songs, most of which emphasise a role in territorial advertisement, mate attraction and maintenance of pair and family bonds (Geissmann, 1999; Geissmann \& Orgeldinger, 2000; Haimoff, 1984a; Leighton, 1987).

Gibbon songs are characterised by being speciesspecific and, at least in part, sex-specific (Geissmann, 1993, 1995a; Haimoff, 1983, 1984a; Marler \& Tenaza, 1977; Marshall \& Marshall, 1976; Marshall \& Sugardjito, 1986). When travelling in the Sunda region at the beginning of the last century, Volz
(1904) already noted that he needed not even leave his ship in order to recognise, just by listening to the songs which carried over from the nearest forest, which gibbon species occurred in that particular area.

In recent years, vocal characteristics have been used to assess systematic relationships among hylobatids and to reconstruct their phylogeny (Creel \& Preuschoft, 1984; Geissmann, 1993, in press; Haimoff, 1983; Haimoff et al., 1982, 1984; Marshall, Sugardjito \& Markaya, 1984). Species-specific characteristics of gibbon songs are largely inherited (Brockelman \& Schilling, 1984; Geissmann, 1984, 1993; Tenaza, 1985), and no differences between the singing behaviour of captive and wild gibbons have yet been discovered (e.g. Geissmann, 1993; Haimoff, 1983).

Gibbon songs probably developed from "loud calls" which are common to all great apes and many other Old World monkeys and which are preferentially or exclusively uttered by males (Geissmann, $2000 b$ ). In spite of the species-specific differences, a comparison of the various songs reveals similarities shared by all species, suggesting that gibbon songs are based on a single ancestral pattern, which is apparently not shared with other apes or monkeys (Geissmann, 1993). It is highly probable that the song structure common to all gibbon species may be interpreted in terms of homology, that is as a synapomorphic (derived) characteristic relative to other apes.

Previous authors disagree as to whether the absence of duetting represents the primitive condition in gibbons (Creel \& Preuschoft, 1984), or whether duetting represents the primitive condition (Groves, 1984; Haimoff, 1983; Haimoff et al., 1982). The former hypothesis was based on "the assumption that evolution normally proceeds from simple, unspecialized states to complex, specialized ones" (Creel \& Preuschoft, 1984, p. 603), whereas the reasons supporting the latter hypothesis were either not explicitly formulated (Haimoff, 1983; Haimoff et al., 1982) or explained on the basis that "it is evidently a primitive characteristic for gibbons to 
duet, as all species do it except for klossii" (Groves, 1984, p. 558).

In the present article, the singing behaviour in all gibbon species is compared. Particular attention was paid to the following song characteristics of adult, mated gibbons: (1) the degree of repertoire overlap in males and females, (2) the occurrence of male solo song bouts, (3) the occurrence of female solo song bouts, (4) the occurrence of duet song bouts, (5) the preferred time of day for female and duet singing, and (6) the preferred time of day for male singing. Tracing these variables on the available phylogenetic trees was expected to enable the identification and reconstruction of the processes involved in the evolution of duetting in gibbons.

\section{MATERIALS AND METHODS}

\section{(1) General methods}

The gibbon classification used here follows Geissmann (in press) and Geissmann et al. (2000), and is summarised in Table 1.

Calls of nine gibbon species (Hylobates agilis, H. lar, H. moloch, H. pileatus, Nomascus concolor, N. gabriellae, $\mathcal{N}$. leucogenys, $\mathcal{N}$. sp. cf. nasutus, and Symphalangus syndactylus) were tape-recorded by the author during several field trips to China, Indonesia, Laos, Malaysia, Thailand and Vietnam in 1990-2001.
Songs of all gibbon species were tape-recorded from gibbons kept in zoos, primate centers and from privately owned animals in China, England, France, Germany, Indonesia, Italy, Laos, The Netherlands, Singapore, Switzerland, Thailand, the United States and Vietnam (Table 2) in 1980-2001. Additional tape-recordings of gibbon songs were kindly made available to the author by more people than can be listed here. Particularly important to the present study were tape-recordings made by Dr Lan Daoying (Bunopithecus hoolock), Mr. Vincent Nijman (H. muelleri), Dr M. Schwarz (duet H. lar male and $H$. moloch female), and Dr R. R. Tenaza (H. klossii).

Descriptions and sonagrams of wild gibbon vocalisations have appeared in a large number of publications. Many of these data were used to supplement those collected during this study. The sources for those data are listed in Table 3, arranged by species.

Most tape-recordings carried out by the author (and all gibbon songs recorded in the field) were made with a Sony TC-D5M tape recorder equipped with a Sennheiser ME 80 (+K3U) directional microphone. Sonograms of tape-recorded vocalisations were generated with SoundEdit 2.0.1 software (see Schmidt, Radin \& Brodie, 1989) on an Apple Macintosh IIci personal computer using a Sound Recorder device (Farallon). These sounds were sampled at $11 \mathrm{kHz}$, and sonagrams were created with a Fast-Fourier transformation (FFT) size of 1024 points.

Table 1. Main divisions of the gibbons (Hylobatidae) (modified after Geissmann, 1995a)

\begin{tabular}{|c|c|c|c|c|}
\hline Genus & $\begin{array}{l}\text { Diploid number } \\
\text { of chromosomes }\end{array}$ & Other group names & Species & Common name \\
\hline Hylobates & 44 & Lar group & $\begin{array}{l}\text { H. } \text { agilis }^{\mathrm{a}} \\
\text { H. klossii } \\
\text { H. lar } \\
\text { H. moloch } \\
\text { H. muelleri } \\
\text { H. pileatus }\end{array}$ & $\begin{array}{l}\text { Agile gibbon } \\
\text { Kloss's gibbon } \\
\text { White-handed gibbon } \\
\text { Silvery gibbon } \\
\text { Grey gibbon } \\
\text { Pileated gibbon }\end{array}$ \\
\hline Bunopithecus & 38 & & B. hoolock & Hoolock \\
\hline Nomascus & 52 & $\begin{array}{l}\text { Concolor group, } \\
\text { crested gibbons }\end{array}$ & $\begin{array}{l}\mathcal{N} . \text { concolor } \\
\mathcal{N} . \text { sp. cf. nasutus } \\
\mathcal{N} . \text { gabriellae } \\
\mathcal{N} . \text { leucogenys }^{\mathrm{b}}\end{array}$ & $\begin{array}{l}\text { Western black crested gibbon } \\
\text { Eastern black crested gibbon } \\
\text { Yellow-cheeked crested gibbon } \\
\text { White-cheeked crested gibbon }\end{array}$ \\
\hline Symphalangus & 50 & & S. syndactylus & Siamang \\
\hline
\end{tabular}

a including $H$. agilis albibarbis.

b including $\mathcal{N}$. leucogenys siki. 
Table 2. Number of institutions where songs of captive gibbons were tape-recorded for this study

\begin{tabular}{|c|c|c|c|c|c|c|c|c|c|c|c|}
\hline \multirow[b]{2}{*}{ Location } & \multicolumn{11}{|c|}{ Species $^{\mathrm{a}}$} \\
\hline & ag & $\mathrm{kl}$ & la & mo & $\mathrm{mu}$ & pi & ho & co & ga & le & sy \\
\hline $\begin{array}{l}\text { China (6): Beijing Zoo; Gejiu Zoo; Guangzhou Zoo; } \\
\text { Hong Kong Zoo; Shanghai Zoo; Kunming Zoo }\end{array}$ & 1 & & 1 & & & & 5 & 1 & 2 & 2 & 1 \\
\hline $\begin{array}{l}\text { England (5): Banham Zoo; Bekesbourne, Howletts Zoo; } \\
\text { Paignton Zoo; Southport Zoo; Twycross Zoo }\end{array}$ & 2 & 1 & 4 & 2 & 3 & 1 & & 1 & & 1 & 3 \\
\hline $\begin{array}{l}\text { France (8): Asson Zoo; Clères Zoo; Doué-la-Fontaine } \\
\text { Zoo; La Flèche Zoo; Mazé, Mr. J. Bauné; Mulhouse } \\
\text { Zoo; Paris, Jardin des Plantes; Paris, Vincennes Zoo }\end{array}$ & 1 & & 4 & & 2 & 2 & & & 3 & 6 & 1 \\
\hline $\begin{array}{l}\text { Germany (15): Berlin, Tierpark Berlin; Berlin Zoo; } \\
\text { Cottbus Zoo; Dortmund Zoo; Duisburg Zoo; } \\
\text { Eberswalde Zoo; Frankfurt Zoo; Hannover Zoo; } \\
\text { Kronberg, Opel Zoo; Leipzig Zoo; Munich, Zoo } \\
\text { Hellabunn; Münster Zoo; Nordhorn Zoo: Rheine Zoo; } \\
\text { Rostock Zoo }\end{array}$ & 1 & & 4 & 2 & 4 & 2 & & & 1 & 5 & 5 \\
\hline Indonesia (2): Cisarua, Taman Safari; Jakarta Zoo & 2 & 1 & & 2 & 2 & & & & & & 2 \\
\hline Italy (1): Rome Zoo & & & 1 & & & 1 & & & & & \\
\hline Laos (1): Vat Si Muong Temple & & & 1 & & & & & & 1 & 1 & \\
\hline The Netherlands (2): Apenheul, Beekse Bergen & 1 & & & & & & & & & 1 & \\
\hline Singapore (1): Singapore Zoo & 1 & & 1 & & 1 & & & & & & \\
\hline $\begin{array}{l}\text { Switzerland (4): Al Maglio Zoo; Rapperswil, Knie’s } \\
\text { Kinderzoo; Seeteufel Zoo, Studen; Zürich Zoo }\end{array}$ & & 3 & & & & 1 & & & & & 2 \\
\hline $\begin{array}{l}\text { Thailand (2): Bangkok Zoo; Khao Kheow Open Zoo, } \\
\text { Chonburi }\end{array}$ & & 1 & & & & 2 & & & & 1 & \\
\hline $\begin{array}{l}\text { United States (4): Atlanta, Yerkes Regional Research } \\
\text { Primate Center; Miami, Metro Zoo; New York, } \\
\text { LEMSIP Primate Center; West Palm Beach, Lion } \\
\text { Country Safari Park }\end{array}$ & & & 4 & & & & & & & & 2 \\
\hline Vietnam (1): Saigon Zoo & & & & & & & & & 1 & & \\
\hline Total number of institutions (50) & 9 & 2 & 24 & 6 & 12 & 9 & 5 & 2 & 8 & 17 & 16 \\
\hline
\end{tabular}

a Abbreviations: ag $-H$. agilis; $\mathrm{kl}-H$. klossii; la $-H$. lar; mo $-H$. moloch; mu $-H$. muelleri; pi $-H$. pileatus; ho $-B$. hoolock; co $-\mathcal{N}$. conolor; ga $-\mathcal{N}$. gabriellae; le $-\mathcal{N}$. leucogenys; sy - S. syndactylus.

\section{(2) Bioacoustic terms and definitions}

The acoustic terminology used here largely follows that proposed by Haimoff $(1984 a)$. A song is what fulfils the criteria set forth by Thorpe (1961, p. 15): "What is usually understood by the term song is a series of notes, generally of more than one type, uttered in succession and so related as to form a recognisable sequence or pattern in time", or, a song is a succession of phrases with non-random succession probability ("Strophenfolgen mit nicht-zufälliger Folgewahrscheinlichkeit", Tembrock, 1977, p. 33). Song bouts are separated from each other by an arbitrarily defined interval of at least $5 \mathrm{~min}$. A duet occurs when one individual coordinates its vocal- isations in time or type of vocalisation with those of another individual (Seibt \& Wickler, 1982; Wickler, 1974). Accordingly, a duet song is a song jointly uttered by two individuals and coordinated in time or phrases.

Within a gibbon song, a note is any single continuous sound of any distinct frequency or frequency modulation, which may be produced during either inhalation or exhalation. A phrase identifies a single vocal activity consisting of a succession of notes which are produced together in a characteristic manner, but which also may be produced independently. Gibbon song bouts consist of phrases and occasional single notes. Great-calls are the most stereotyped and most easily identifiable 
Table 3. References for information on vocalisations of wild gibbons used for the present study

\begin{tabular}{|c|c|c|}
\hline Species & $\begin{array}{l}\text { Own } \\
\text { observation } \\
\text { (this study) }\end{array}$ & References \\
\hline Hylobates agilis & + & $\begin{array}{l}\text { Brockelman \& Gittins (1984); Gittins (1978, 1984b); Gittins \& Raemaekers } \\
\text { (1980); Haimoff }(1984 b) \text {; Haimoff \& Gittins (1985); Marshall }(1981) \text {; } \\
\text { Mather (1992); Mitani }(1987 a, b, 1988,1990) \text {; Mitani \& Marler (1989) }\end{array}$ \\
\hline H. klossii & & Haimoff \& Tilson (1985); Tenaza (1976); Whitten $(1982,1984)$ \\
\hline H. lar & + & $\begin{array}{l}\text { Brockelman \& Schilling (1984); Caldecott \& Haimoff (1983); Chivers } \\
\text { (1974); Marshall (1981); Mather (1992); Raemaekers \& Raemaekers } \\
(1984 a, b, 1985 a, b) \text {; Raemaekers et al. (1984); Tenaza (1985) }\end{array}$ \\
\hline H. moloch & + & $\begin{array}{l}\text { Dallmann \& Geissmann (2001, in press); Geissmann \& Nijman (2000); } \\
\text { Kappeler (1984) }\end{array}$ \\
\hline H. muelleri & & $\begin{array}{l}\text { Haimoff }(1985 b) \text {; Mitani }(1984,1985 a, b, c, 1987 a) \text {; MacKinnon, 1974; } \\
\text { Mather (1992); Tenaza (1985) }\end{array}$ \\
\hline H. pileatus & + & $\begin{array}{l}\text { Brockelman \& Schilling (1984); Mather (1992); Srikosamatara (1980); } \\
\text { Srikosamatara \& Brockelman }(1983,1987)\end{array}$ \\
\hline Bunopithecus hoolock & & $\begin{array}{l}\text { Choudhury (1989); Feeroz \& Islam (1992); Gittins \& Tilson (1984); } \\
\text { Haimoff }(1985 a)\end{array}$ \\
\hline Nomascus concolor & + & $\begin{array}{l}\text { Geissmann et al. (2000); Haimoff et al. (1987); Jiang \& Wang (1997); } \\
\text { Lan (1993) }\end{array}$ \\
\hline N. sp. cf. nasutus & + & Geissmann (1997); Geissmann et al. (2000) \\
\hline N. gabriellae & + & Adler (1991); Geissmann $(1995 b)$ \\
\hline N. leucogenys & + & Hu et al. (1989) \\
\hline Symphalangus syndactylus & + & Chivers $(1974,1976)$; MacKinnon, 1974; West (1982) \\
\hline Various species & & $\begin{array}{l}\text { Chivers (1978); Gittins (1984a); Haimoff }(1983,1984 a) \text {; Haimoff et al. } \\
\text { (1982, 1984); Marler \& Tenaza (1977); Marshall \& Marshall (1976, } \\
\text { 1978); Marshall \& Sugardjito (1986); Marshall et al. }(1972,1984)\end{array}$ \\
\hline
\end{tabular}
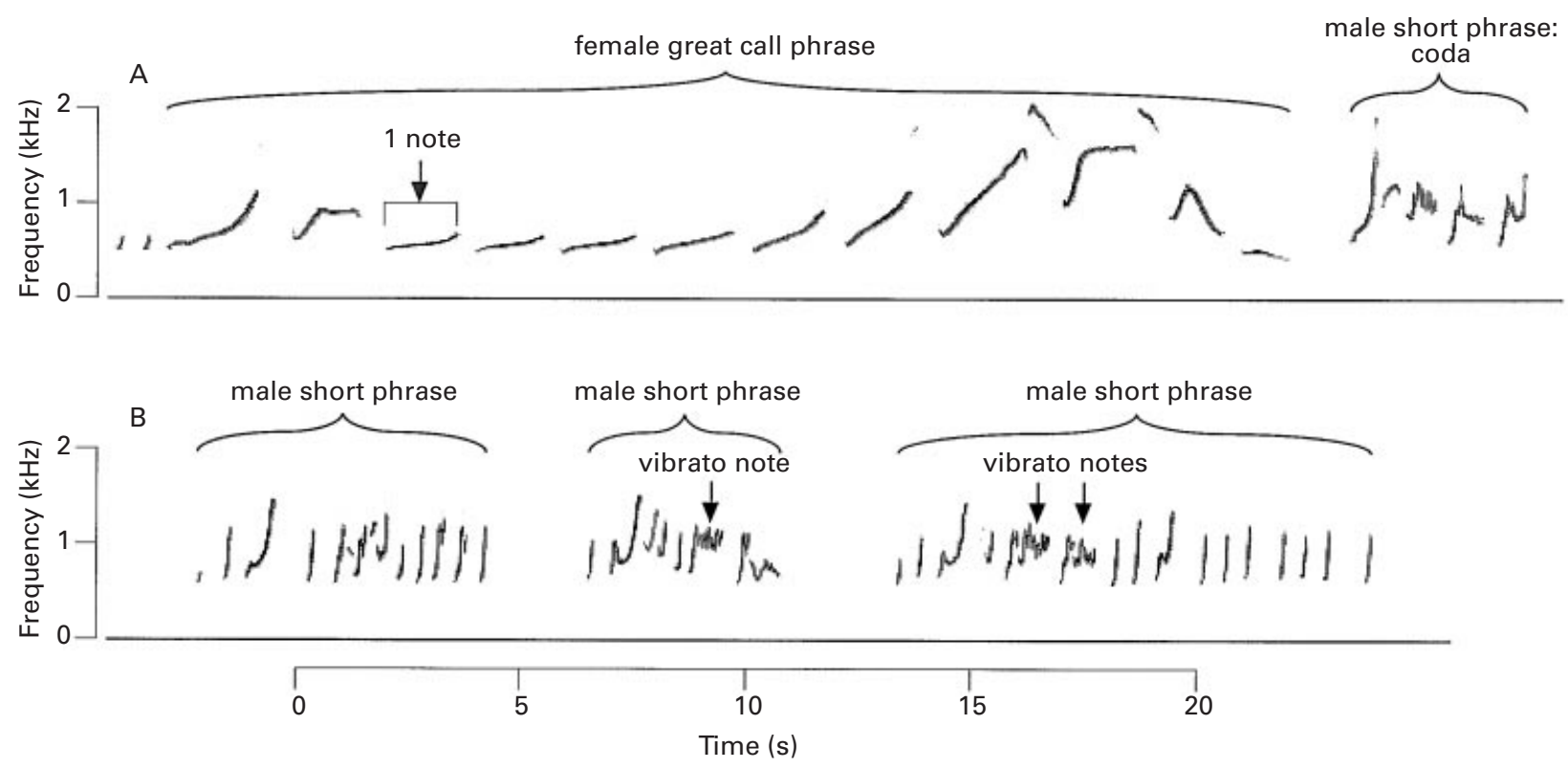

Fig. 1. Sonograms of (A) an excerpt of a duet song of H. lar (Mulhouse Zoo, France, 15 September 1988) and (B) an excerpt of a male solo song of the same species (Twycross Zoo, United Kingdom, 3 October 1988), illustrating the terms "phrase", "note", "great-call" and "coda"). 
phrases of gibbon song bouts and are produced by females of all gibbon species. All other phrases are termed short phrases here. A particularly characteristic short phrase in gibbon duet songs is the male's coda, which is produced at or near the end of the female's great-call. The combination of a female great-call and the corresponding coda is called a "great-call sequence". The short phrases occurring between the great-call sequences are termed "interlude sequences". A typical cycle of events occurring several times in a gibbon duet call bout begins with male short phrases (with or without female short phrases), followed by the onset of a female great-call. The male falls silent during the build-up phase of the great-call and adds a coda at the climax. After that, he resumes producing short phrases (again, with or without female short phrases). Fig. 1 shows two sonograms illustrating some of the terms used in this paper: note, great-call, short phrase, and coda.

\section{RESULTS}

\section{(1) Degree of repertoire overlap in males and females}

\section{(a) Phrase repertoire}

Sex-specificity in gibbon songs can occur in least two different respects: (1) in the repertoire of note types used by either sex, and (2) in the repertoire of phrases built up from these note types by either sex. Neither of these two aspects have apparently been quantified for any gibbon species so far. The reason for this lies in the difficulty of identifying the number of different note types which make up a gibbon's song repertoire, especially when looking at notes which gradually change their aspect (e.g. during a great-call, see below). Similarly, it is problematic to identify the number of different short phrases used by a gibbon, because these phrases are highly variable in structure. Thus, the following assessment of repertoire overlap in males and females must remain preliminary. I will briefly discuss first repertoire overlap of phrases and then repertoire overlap of note types.

The following comparison between male and female vocalisations covers each sex's entire song repertoire. Figs 2 and 3 present typical song phrases of male and female gibbons. The phrase repertoire of gibbons may, using a very simplified approach, be divided into great-call phrases and short phrases. All gibbon females exhibit a spectacular, stereotyped and readily recognisable phrase known as the greatcall (Fig. 2). In all species, the great-call consists of a series of notes, uttered with increasing speed (although the acceleration is barely noticeable in $H$. agilis and $H$. lar). In all species except $B$. hoolock and $S$. syndactylus, an increase in the maximum frequency of the notes also occurs during the great-call. During their song bouts, females repeat great-calls at quite regular intervals of approximately one to a few minutes. Adult, mated males are not known to produce great-calls. Instead, they produce short phrases only. In most species, females are also known to produce short phrases. The only exception is the crested gibbons (genus Nomascus): adult female crested gibbons contribute only great-calls or greatcall fragments to the duet song. As a result, songs of male and female crested gibbons exhibit no overlap in their phrase repertoire and show the highest degree of sex specificity in this respect.

The short phrases of males (and females) are usually less stereotypic than the great-calls (Fig. 3). Whereas female great-calls remain essentially unchanged throughout a song bout, successive short phrases are rarely identical. Instead, males gradually build up their phrases during a song bout, beginning with single, simple notes. As less simple notes are introduced, these notes are combined to form increasingly complex phrases, reaching the fully developed form only after several minutes of singing. In all but two species, males tend to reply to female great-calls with special variants of their short phrases, the so-called codas (shown in Fig. 2). Males of $H$. klossii and $H$. moloch are unusual in that they are not known to produce codas. Usually, male and female song bouts do not even overlap in mated pairs of these two species (see Section III.4).

Interestingly, gibbons appear to recognise, and may respond to, great-calls of other species. In zoos with several gibbon cages in close proximity, neighbouring pairs of different species may engage in synchronous call bouts with great-calls of several species uttered in concert. In captivity, typical greatcall sequences with male codas are produced by pairs of mixed-species combinations such as, for instance: $H$. pileatus $-H$. lar, $H$. agilis $-H$. muelleri, $H$. pileatus - N. gabriellae, and a $H$. lar male and a $H$. moloch female. An excerpt of a duet song bout of the latter pair is shown in Fig. 4. In this sonogram, the male produces short phrases during the interlude sequence, interrupted by the introductory notes of the female's great-call. The male falls silent during the great-call and adds a coda at its end. This example is of particular interest when discussing the 


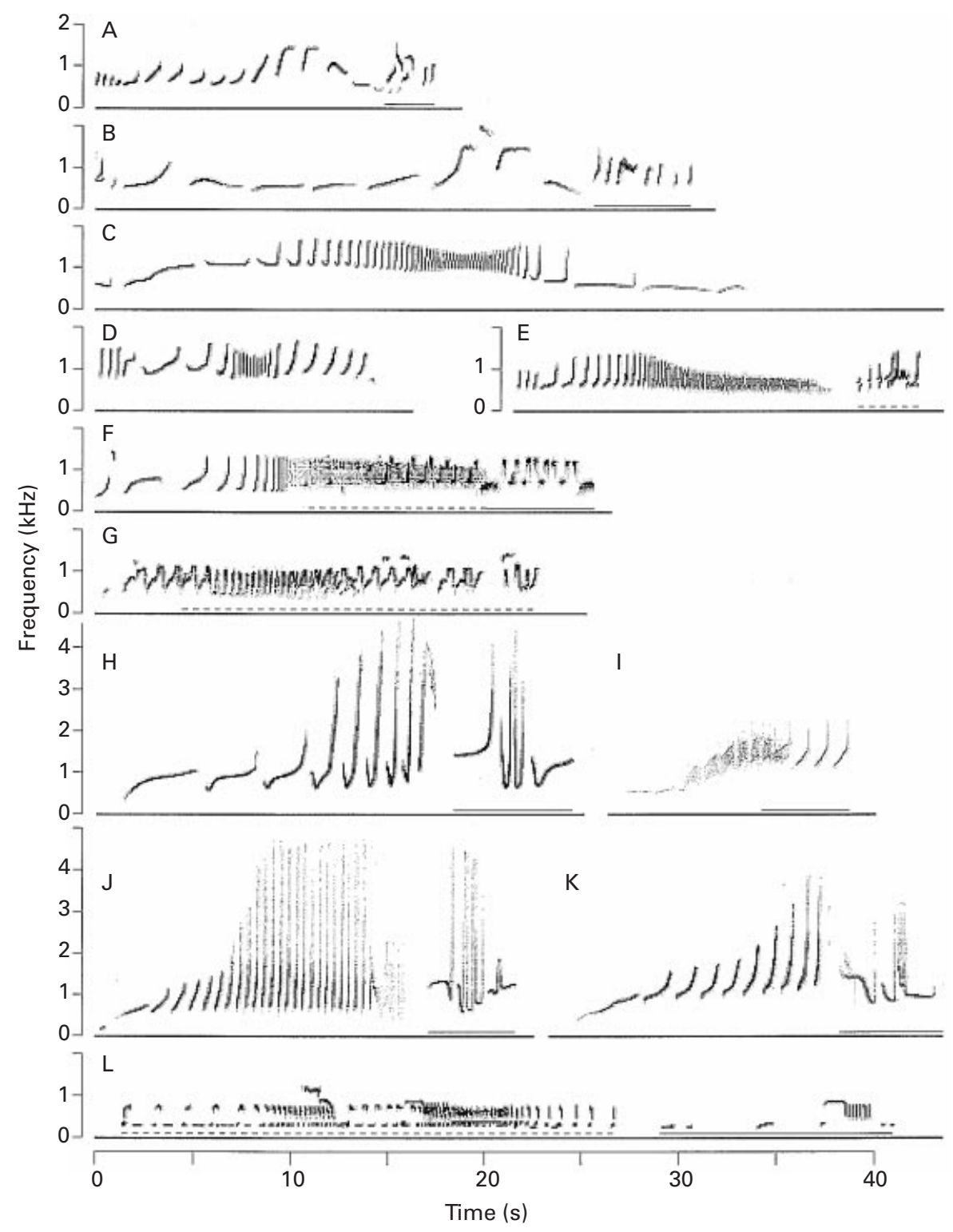

Fig. 2. Sonograms of great-call sequences of all gibbon species. C and D are excerpts from female solo song bouts; all other sonograms show duets. Male solo contributions to duets are underlined with a solid line, synchronous male and female vocalisations are underlined with a dashed line. (A) H. agilis (Asson Zoo, 31 May 1988); (B) H. lar (Paignton Zoo, 20 October 1988); (C) H. klossii (South Pagai, 27 November 1987, recorded by Dr R. R. Tenaza); (D) H. moloch (Munich Zoo, 16 July 1987), (E) H. muelleri (Paignton Zoo, 22 October 1988); (F) H. pileatus (Zürich Zoo, 5 May 1988); (G) B. hoolock (Kunming Zoo, 27 July 1990); (H) N. concolor (Xujiaba, Ailao Mountains, China, 1 August 1990); (I) N. sp. cf. nasutus (Bawangling Nature Reserve, Hainan, China, 15 October 1993); (J) N. leucogenys (Paris, Ménagerie, 17 May 1988); (K) N. gabriellae (Mulhouse Zoo, 13 September 1988); (L) S. syndactylus (Metro Zoo, Miami, 31 July 1988).

evolution of duetting in gibbons. It documents that great-calls of $H$. moloch females may elicit a coda response from males of other species, although they do not have this effect on males of their own species and that typical gibbon duets with $H$. moloch females are possible, although pure pairs of $H$. moloch do not duet.

\section{(b) Note type repertoire}

All gibbon species use a variety of different note types. The hoolock, Bunopithecus hoolock, is unique in that its note repertoire does not appear to include sex-specific note types. This has been mentioned in virtually every study on the vocal repertoire of this 


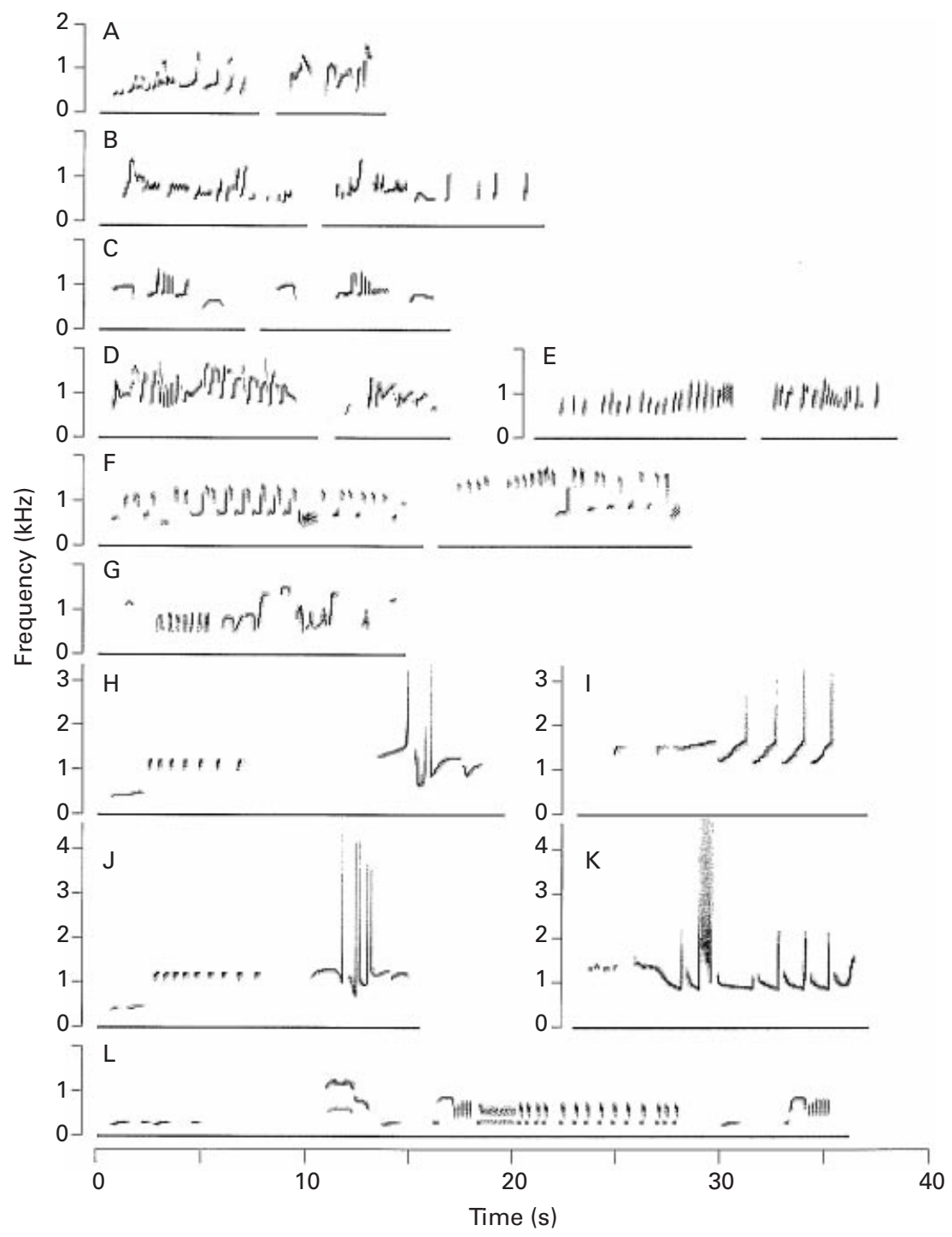

Fig. 3. Sonograms of fully developed male phrases of all gibbon species. In order to show variability, sonograms of two different phrases are provided for species A-F. In $H$. klossii $(\mathrm{F})$, these stem from the same male; in all other cases, two different individuals are shown. (A) H. agilis (Twycross Zoo, 2 October 1988; and Guangzhou Zoo, 7 September 1990); (B) H. lar (Rheine Zoo, 5 July 1987; and Twycross Zoo, 3 October 1988); (C) H. klossii (both phrases from Twycross Zoo, 2 October 1988); (D) H. moloch (Munich Zoo, 16 July 1987; and Howletts Zoo, 17 October 1988), (E) H. muelleri (Doué-la-Fontaine Zoo, 25 May 1988; and Banham Zoo, 14 October 1988); (F) H. pileatus (Zürich Zoo, 5 May 1988; and Berlin Zoo, 29 June 1988); (G) B. hoolock (Kunming Institute of Zoology, October 1988, recorded by Dr Lan Daoying); (H) N. concolor (Gejiu Zoo, 2 August 1990); (I) N. sp. cf. nasutus (Bawangling Nature Reserve, Hainan, China, 21 October 1993); (J) N. leucogenys (Paris, Ménagerie, 17 May 1988); (K) N. gabriellae (La Flèche Zoo, 29 May 1988); (L) S. syndactylus (Howletts Zoo, 16 October 1988).

species, starting with Marshall and Marshall (1976) and Marler and Tenaza (1977), and was confirmed during the present study. Although the adult male does not produce great-call phrases, all great-call note types per se occur in the short phrases of both males and females. In all other gibbon species, greatcall notes are sex-specific.

Crested gibbons (genus Nomascus), represent the other extreme of the spectrum: they show the highest degree of sex-specificity in their note type repertoire. Males and females both produce several note types, each of which is not normally produced by adult conspecifics of the opposite sex. This has been repeatedly documented in earlier studies (e.g. Deputte, 1982; Schilling, 1984) and was confirmed during the present study in all species of the genus, either in the wild or in captivity.

In all remaining gibbon species (genera Hylobates 


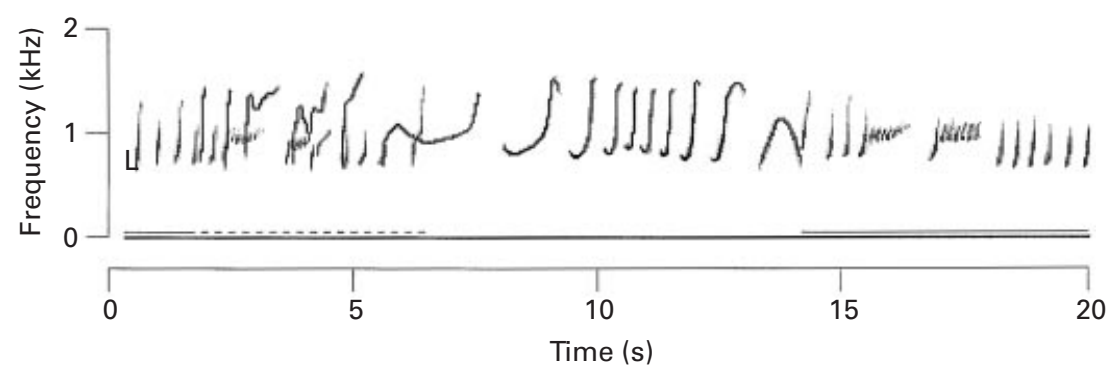

Fig. 4. Sonogram of great-call sequence of a mixed pair: H. lar (male) and H. moloch (female). Knie's Kinderzoo, Rapperswil, 30 April 1979 (recorded by Dr M. Schwarz). Male solo contributions are underlined with a thin solid line, synchronous male and female vocalisations are underlined with a thin dashed line.

Table 4. Combined summary of literature data and data resulting from this study

\begin{tabular}{|c|c|c|c|c|c|c|}
\hline \multirow[b]{2}{*}{ Species } & \multicolumn{6}{|l|}{ Character } \\
\hline & $\begin{array}{l}\text { 1. Degree of sex- } \\
\text { specificity of } \\
\text { song repertoire }\end{array}$ & $\begin{array}{l}\text { 2. Male } \\
\text { solo song } \\
\text { bouts }\end{array}$ & $\begin{array}{l}\text { 3. Female solo } \\
\text { song bouts }\end{array}$ & $\begin{array}{l}\text { 4. Duet song } \\
\text { bouts }\end{array}$ & $\begin{array}{l}\text { 5. Time of } \\
\text { day for } \\
\text { duet/female } \\
\text { songs }\end{array}$ & $\begin{array}{l}\text { 6. Time of } \\
\text { day for } \\
\text { male songs }\end{array}$ \\
\hline H. agilis & intermediate & present & absent & present & dawn & pre-dawn/dawn \\
\hline H. klossii & intermediate & present & present & absent & dawn & pre-dawn/dawn \\
\hline H. lar & intermediate & present & absent & present & dawn & pre-dawn/dawn \\
\hline H. moloch & intermediate & rare & present & absent & dawn & pre-dawn/dawn \\
\hline H. muelleri & intermediate & present & $\begin{array}{l}\text { absent } \\
\text { or rare (?) }\end{array}$ & present & dawn & pre-dawn/dawn \\
\hline H. pileatus & intermediate & present & absent & present & later & later \\
\hline B. hoolock & small & absent & absent & present & later & n.a. \\
\hline $\mathcal{N}$. concolor & large & absent & absent & present & dawn & n.a. \\
\hline $\mathcal{N}$. sp. cf. nasutus & large & absent & absent & present & dawn & n.a. \\
\hline $\mathcal{N}$. gabriellae & large & absent & absent & present & dawn & n.a. \\
\hline $\mathcal{N}$. leucogenys & large & absent & absent & present & dawn & n.a. \\
\hline S. syndactylus & intermediate & absent & absent & present & later & n.a. \\
\hline
\end{tabular}

n.a. $=$ not applicable, because mated males do not usually sing solo songs.

and Symphalangus), adult males and females share a certain part of the note type repertoire, but also use some sex-specific notes. In gibbons of the genus Hylobates, the shared notes include various variants of wa-notes which make up a large proportion of the song repertoire, whereas the great-call notes are female-specific, and some other notes are male specific, like the vibrato notes in $H$. lar (visible in Fig. 1). In Symphalangus syndactylus, the part of the repertoire shared by males and females includes various barks and booms, whereas the long barks of the great-call are female-specific, and the bitonal scream is male-specific (Geissmann, 2000a).

\section{(c) Repertoire overlap: Synthesis}

In summary, roughly three classes of sex-specificity can be differentiated (Table 4). The genus Nomascus exhibits the largest specificity: there is no overlap between the sexes in note repertoire and no overlap in the phrase repertoire. Female song contributions consist of great-calls only which consist of femalespecific notes, whereas males produce short phrases only, and these consist of male-specific notes. The genus Bunopithecus, on the other hand, exhibits the smallest degree of vocal sex specificity: although only females produce great-call phrases, both sexes use the same note repertoire and produce the same types of short phrases.

All other gibbons are intermediate in their degree of vocal sex specificity: only females produce greatcalls, which include female-specific note types. Both males and females produce short phrases, which may, however, include sex-specific notes in males (exceptions: $H$. pileatus, and, possibly, $H$. agilis and H. muelleri). 
Although all gibbon species show at least some degree of sex-specific repertoire, as shown above, it should be noted that typical male and typical female duet parts can be sung by individuals of the opposite sex. This has been observed in immature animals (Geissmann, 1993), unmated or freshly mated animals (Geissmann, 1983; Srikosamatara, 1982) or gibbons in other unusual situations (Schilling, 1984).

\section{(2) Occurrence of male solo song bouts}

Mated males of most gibbon species may engage in uninterrupted solo song bouts of considerable length, sometimes lasting more than $2 \mathrm{~h}$, but mated males of $B$. hoolock, S. syndactylus and of all crested gibbons (genus Nomascus) usually sing in duet with their females only (duet songs are described below).

Evidence on $H$. pileatus is somewhat contradictory. Srikosamatara and Brockelman (1983) mention solo songs of unmated males only, but Brockelman (personal communication cited in Haimoff, 1983, p. 225) observed that males produced solo songs in a chorus, like other species of the lar group. During a brief survey at Khao Soi Dao Wildlife Sanctuary (NE Thailand), I recorded 51 song bouts in five days, $14(27 \%)$ of which were male solo song bouts (T. Geissmann, unpublished data). Unless there was an unusually high proportion of unmated males in our study area, some of the solo-singing males were mated. I observed seven captive pairs of $H$. pileatus (Berlin, Zoo, Twycross Zoo, Zürich Zoo), five of which regularly produced male solo song bouts. These observations suggest that solo songs of mated males are not uncommon in $H$. pileatus.

It has been questioned whether mated males of $H$. moloch sing at all. During 130 full days of listening scattered over the whole year, none of the five resident mated males in Kappeler's study area ever performed a song bout, suggesting "that territorial male moloch gibbons do not sing" (Kappeler, 1984). Only two male song bouts were heard during that study, one by an unmated individual on the border between two territories and one by an unidentified individual singing outside the study area. During a short study in Central Java, however, male solo songs appeared to be more common, amounting to approximately $10 \%$ of all song bouts heard $(\mathrm{N}=$ 125, Geissmann \& Nijman, 2000; T. Geissmann + V. Nijman, in preparation). In conclusion, it appears that solo songs of mated males do occur, but may be relatively rare in this species.

\section{(3) Occurrence of female solo song bouts}

Mated females of most gibbon species do not normally produce solo song bouts, with two exceptions: females of $H$. klossii and $H$. moloch, as a rule, produce solo songs only. Female solo song bouts are of shorter duration than male solo song bouts (usually less than 30 minutes).

There has been some uncertainty as to whether female solo songs occur in mated $H$. muelleri. One early description of $H$. muelleri songs identified male solo songs and female solo songs only (Marshall \& Marshall, 1976). Another early report described song bouts of this species as duet songs during which the male does not contribute to the interlude sequences, but simply adds a brief coda to the end of the female's great-call (Marler \& Tenaza, 1977). Later, singing behaviour of this species was described as including male solo songs and duet song bouts, and occasional solo songs of females (Mitani, 1984). More recent reports on songs of Mueller's gibbon fail to mention female solo songs altogether (Haimoff, $1985 b$; Marshall \& Sugardjito, 1986) or explicitly state that they do not occur in this species (Leighton, 1987). Although some female solo songs are included in a collection of tape-recordings made by Vincent Nijman in the Balikpapan area (SE-Kalimantan), it is not known whether these songs were produced by mated or unmated individuals. Only two pure pairs of $H$. muelleri were available during the present study. One of them produced several duet song bouts. The female of the second pair uttered three solo song bouts. The male contributed a few single wa-notes to the female songs, but no song phrases at all. The same male produced one solo song bout. With the information available at present, it appears reasonable to assume that female solo songs may occasionally occur in $H$. muelleri, but are not customary.

\section{(4) Occurrence of duet song bouts}

Whereas mated females of $H$. klossii and $H$. moloch have been reported to produce solo song bouts, mated females of other species usually confine their singing behaviour to duet song bouts only. Duet song bouts, like female song bouts, usually have a duration of less than $30 \mathrm{~min}$. All gibbon species produce duet song bouts with two exceptions: $H$. moloch and $H$. klossii. Although it is generally accepted that males of $H$. moloch and $H$. klossii do not contribute vocally to the great-calls of the females, there has been some controversy about whether these two species produce 
duet song bouts at all. In his paper on vocalisations of H. klossii, Tenaza (1976) mentions that "males utter short, soft whistles during 25-50\% of the intervals between successive female songs" and explains later in the same paper: "Unlike other gibbons that have been studied, in which mated males and females sing duets with their mates, Kloss' gibbons sing in all-male and all-female choruses."

In contrast to this view, other authors have since reported that mated $H$. klossii perform duets in a substantial proportion of their interlude sequences (Cowlishaw, 1992; Haimoff, 1983,1984a; and Whitten, 1980, cited as evidence in all three publications). Subsequent to his publication (Tenaza, 1976) on the singing behaviour of $H$. klossii on Siberut Island, R. R. Tenaza (personal communication, November 1992) was able to supplement the results of his earlier study by additional observations made on $H$. klossii in the Pagai islands. These more recent observations apparently confirmed that this species does not duet. On occasion, a late-morning male chorus would overlap a female chorus, but a male and a female from the same pair were never heard to participate in these overlapping choruses. The short, soft, monosyllabic whistle often produced by males between great-calls of their mates does not necessarily represent a song contribution. "Rarely if ever did a male whistle more than once between songs [i.e. great-calls] of his mate" (R. R. Tenaza, personal communication, November 1992). Similar whistles precede male song (Tenaza, 1976), but also occur when undisturbed gibbons are simply travelling or foraging (R. R. Tenaza, personal communication, November 1992).

The same authors who recognise duetting in the songs of $H$. klossii also recognise it in the songs of $H$. moloch, in contrast to Kappeler $(1981,1984)$, who never heard duet songs during his field study. I had the opportunity to listen to all of Kappeler's many original tape-recordings, and found no evidence for duetting. There was no vocal contribution of the males to the female songs. Similar to Kappeler's observation, no duet songs were heard among 125 call bouts heard in Central Java Geissmann \& Nijman, 2000; T. Geissmann + V. Nijman, in preparation). Males appear actively to avoid singing together with their mates: I repeatedly observed males of $H$. moloch, both in the wild and in captivity, to abort an ongoing song bout as soon as a female song bout started.

As evidence for duetting in $H$. moloch, Haimoff (1983) cites tape-recordings he made of a captive gibbon pair at Bristol Zoo, and Cowlishaw (1992) cites a tape-recording made by Marshall and Marshall (1976) in Java. Duetting of the pair at Bristol Zoo should not be cited for this purpose, however, because the male of this pair was not $H$. moloch but $H$. muelleri abbotti (as identified by Geissmann, 1993, p. 182).

Some kind of communal calling appears to occur, however, in the Marshalls' tape-recording of wild $H$. moloch (later published on a phonograph disc: Marshall \& Marshall, 1978). It appears to be identical to the "border conflicts between neighbouring groups" described by Kappeler (1984). I witnessed one similar call bout spontaneously produced by the family group at the Berlin Zoo, consisting of the breeding pair and a juvenile male. All three members of the group contributed loudly to the interlude sequences, which consisted of brief outbursts of loud series of simple $w a$-notes. The males abruptly stopped calling each time the female started a great-call, but did not add a coda at its end. On the following day, this tape-recording was played back to the group. The animals reacted by producing the same communal wa-phrases in synchrony with those presented on the tape-recording. A few communal call bouts were also heard in Central Java; one of these was elicited by the playback of a female solo song bout presented on the common territory boundary of two neighbouring groups ( $\mathrm{T}$. Geissmann, personal observations).

In conclusion, it appears that $H$. klossii and $H$. moloch, as a rule, produce only solo songs. Hylobates moloch may occasionally engage in communal call bouts which reportedly occur in specific situations and which may include great-calls at irregular intervals. These were not considered to be duet songs, either in Kappeler's (1984) study or in the present one.

\section{(5) Time of day of duet/female song bouts}

Gibbons preferentially utter their song bouts in the early morning hours. The time at which each species tends to produce the majority of duet song bouts (and female solo song bouts) can be divided into two categories: at or soon after dawn $(H$. agilis, H. klossii, H. lar, H. moloch, H. muelleri, crested gibbons), and 2-3 h later in the morning (H. pileatus, B. hoolock, $S$. syndactylus).

\section{(6) Time of day of male song bouts}

The time at which each species tends to produce most male solo song bouts can be divided into two 
categories: in the dark before dawn $(H$. agilis, $H$. klossii, H. moloch, H. muelleri) or around dawn ( $H$. lar), and about $2-3 \mathrm{~h}$ after dawn (H. pileatus). In those species where male solo song bouts occur, the solo songs tend to start approximately $1-3 \mathrm{~h}$ prior to the duet song bouts.

The character states found in this study are listed in Table 4.

\section{DISGUSSION}

\section{(1) Song-splitting}

Wickler and Seibt (1982) outlined three alternative routes in order to explain how duet songs could have evolved: "(a) through song merging: two individuals combine their respective songs in a more or less complicated manner; or (b) through song copying: individuals copy their partner's song; or (c) through song-splitting: a given song is divided up between the partners."

Only routes (a) and (c) would be expected to lead to duets with mates having a sex-specific repertoire, as is typical of most gibbon species. By contrast, route (b) requires that "individuals take over the partner's vocalisations and then join him in unisono singing" (Wickler \& Seibt, 1982, p. 138). Unisono singing has not been reported for mated gibbons. All gibbon species use at least one sex-specific phrase (the great-call) in their adult song repertoire. Wickler and Seibt (1982) do not specify how individuals would take over the partner's vocalisations during the course of evolution, but in an earlier paper, these authors describe their example (the African forest weaver Symplectes bicolor) in more detail suggesting that learning may be involved (Wickler \& Seibt, 1980). There is no evidence of gibbons learning parts of their repertoire from other gibbons; instead, there is evidence that the gibbon song repertoire is largely inherited (Brockelman \& Schilling, 1984; Geissmann, 1984, 1993; Tenaza, 1985). Thus, routes (a) and (c) are more likely candidates to explain the evolution of gibbon duets.

In route (a), mates with basically different repertoires may combine them in a duet. This is the song-merging hypothesis. At no transitional stage along this evolutionary route would one expect a mate to be able to sing the other's repertoire. This is more likely to occur in song-splitting (c), where a basic song is divided into two sub-repertoires, each becoming increasingly confined to one sex. The observation that both typical male and typical female duet parts can be sung by individuals of the
Song-splitting

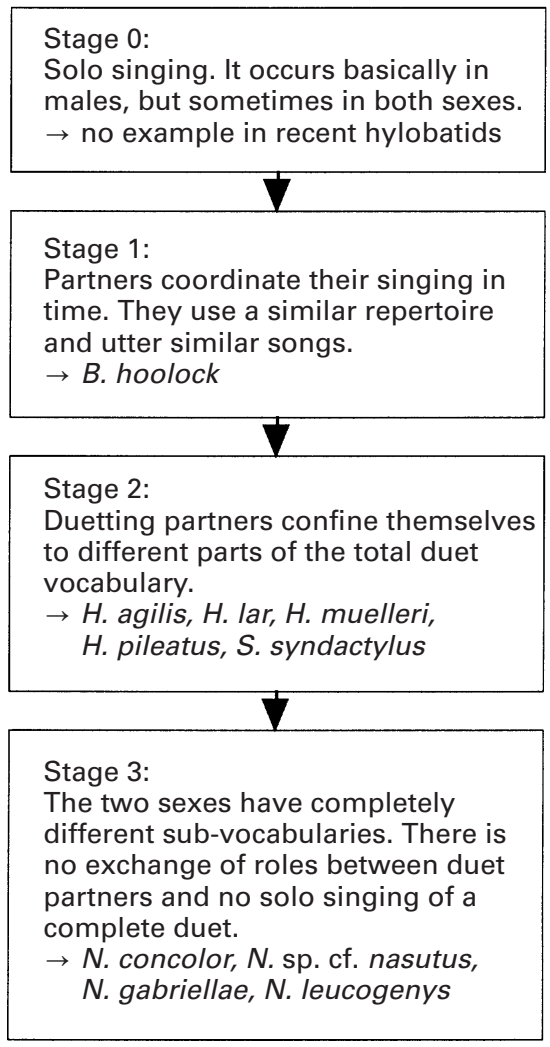

Fig. 5. Gibbon species arranged according to the songsplitting hypothesis. See text for explanation.

opposite sex (see Section III.1c) suggests that songsplitting rather than song merging occurred during the phylogeny of duetting in gibbons.

The song characteristics of the various gibbon species can be arranged linearly according to the degree of sex-specificity of the song repertoire (Fig. 5 ), similar to the stages of song-splitting proposed by Wickler and Seibt (1982) to document the evolution of duetting in some species of birds.

This hypothetical arrangement leads from duets in which both pair partners sing virtually identical duet contributions, through pairs in which the repertoires of both sexes overlap partially, and finally to pairs where the repertoires are completely sexspecific, because each sex confines its vocalisations to only one part of the whole song. This linear arrangement is interpreted as representing an evolutionary trend from solo singing to full partner dependence and increasing song-splitting. The direction of evolutionary change is suggested because the more complex structure is more likely to be derived. Because duet songs of recent gibbon species appear to have preserved several of the hypothetical stages of the song-splitting scenario, they are likely to 
have evolved according to the song-splitting hypothesis as set out by Wickler and Seibt (1982).

The specialisation of the sexes on different parts of the whole song must probably be seen in connection with the frequently proposed possibility that the song contributions of each sex serve different functions and therefore are under different selective pressures (Cowlishaw, 1992; Geissmann, 1983; Gittins, 1978; Marshall \& Marshall, 1976). It should be noted, however, that the arrangement of species presented in Fig. 5 does not necessarily represent a phylogeny. Different species could independently have reached the same stage of song-splitting.

Two species are missing from the arrangement shown in Fig. 5: H. klossii and H. moloch. Their position within the framework of the song-splitting hypothesis will be discussed below.

\section{(2) Duet-splitting}

In some gibbons, another trend can be recognised in addition to the trend of song-splitting. In mated pairs of $H$. pileatus, male solo song bouts occur as well as duet song bouts. The majority of these solo songs are sung approximately $2 \mathrm{~h}$ after dawn but approximately 2 h earlier than duet songs. In $H$. agilis, $H$. lar and $H$. muelleri, however, the first peak of singing activity occurs at or even before sunrise. At this time, the males are reported to produce solo songs on their sleeping trees. The second peak is one to several hours later in the morning, after a first feeding bout. At this time, the females usually join the males in duet songs.

Two gibbon species, H. klossii and $H$. moloch, are exceptional in that the pair partners are reported to sing solo songs only. At first sight, the logical conclusion would be to interpret this condition as a primitive trait, which would fit perfectly into the hypothetical stage zero of Wickler and Seibt's (1982) song-splitting hypothesis (see Fig. 5). In the following discussion, however, three arguments are presented which support an alternative view, that is, solo singing in these two species is derived secondarily from duet singing.

(1) Several different phylogenies have been proposed for hylobatids; some of them are presented in Fig. 6. They are based on morphological, behavioural or molecular characters. Although differing in several details, they share basic similarities. They all agree on the following point: several duetting species, such as $\mathcal{N}$. concolor, $S$. syndactylus and B. hoolock, split off from the main stem of hylobatids before the two non-duetting species did, and several duetting species split off afterwards, such as $H$. muelleri, $H$. agilis and $H$. lar.

The conclusion of this comparison is that, if duetting is primitive and non-duetting is derived, non-duetting must have evolved at least once in gibbons, but maximally twice if the trait has been developed independently in $H$. klossii and in $H$. moloch. If non-duetting is primitive and duetting derived, however, duetting must have evolved at least twice in gibbons, or four to five times if any one of the phylogenetic trees shown in Fig. 6 is realistic. It has been shown elsewhere (Geissmann, 1993) that gibbon duets exhibit a considerable number of characteristics which are shared by all duetting gibbon species. The complexity of the duet pattern renders convergent evolution very unlikely.

(2) In both $H$. klossii and $H$. moloch, only the males sing before dawn in the sleeping trees, whereas the females sing their solos later in the morning. These completely separated singing periods of males and females appear to be the logical consequence of the previously mentioned trend of $H$. agilis, $H$. lar and $H$. muelleri to produce male solo songs before or around dawn, $1-3 \mathrm{~h}$ earlier in the morning than duet song bouts. The gibbon species whose pair partners always duet and those species which do not duet can be linked with these intermediate stages, in which duets are usually separated in time from solo songs. The occurrence of the intermediate stages $3 \mathrm{a}$ and $4 \mathrm{a}$ (see Fig. 7) supports the view that the non-duetting species should be placed in a new, derived position in the evolutionary framework of the song-splitting hypothesis, as shown in Fig. 7. The term "duetsplitting" which is used in Fig. will be explained below.

(3) A final argument results from the observation that the male of a duetting species $(H$. lar $)$ was able to produce a typical duet with the female of a nonduetting species, H. moloch (Fig. 4). The two gibbons produced a well-coordinated duet; the organisation of their interaction in the great-call sequence is virtually identical to that of duetting gibbon species. Apparently, the female song of $H$. moloch fulfils all the requirements for duetting, although this species is not known to duet during the great-call sequence. Moreover, this is not simply a male $H$. lar which follows the female great call with a coda and thus creates the duet, but it is also the female $H$. moloch following the male's short phrases with her great call. The female, too, chooses to duet with this male and to insert great calls in his song. This does not normally occur in pure pairs of $H$. moloch. This observation provides additional support for the 
A

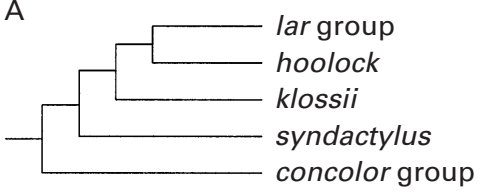

C

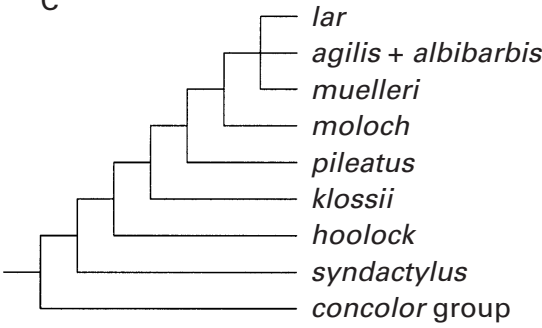

E

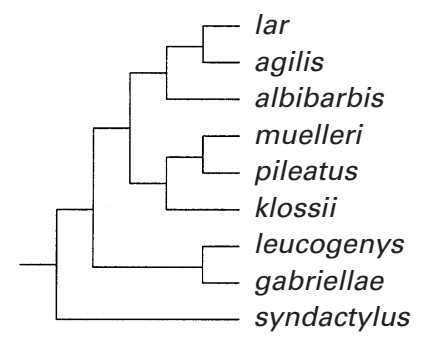

G
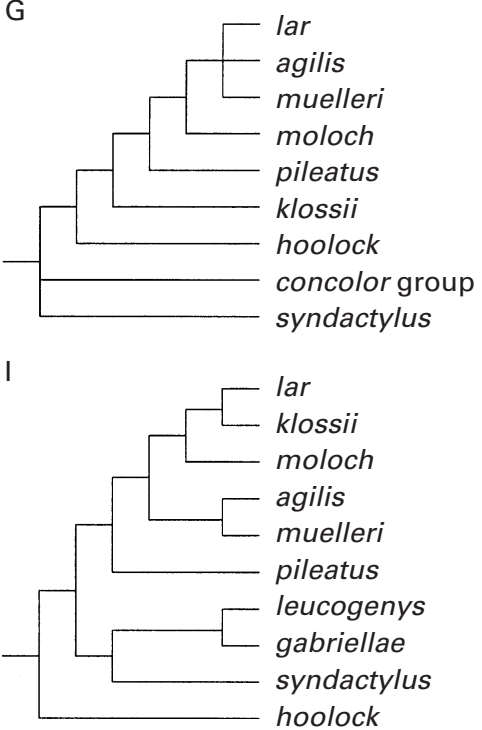
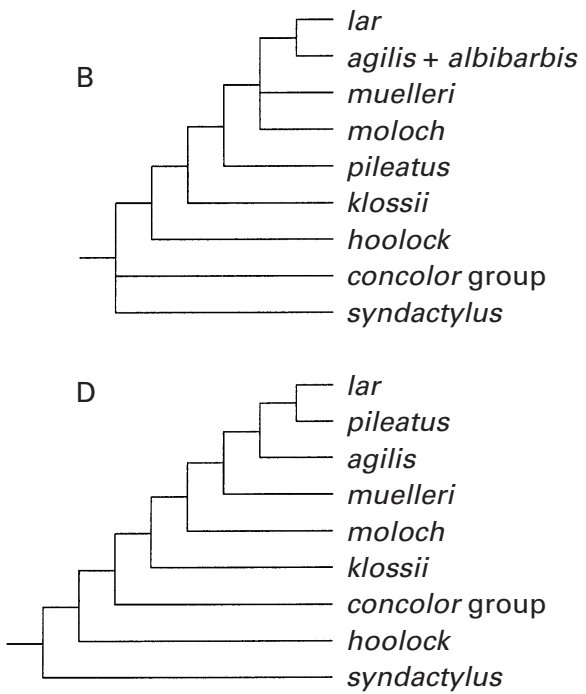

$\mathrm{F}$

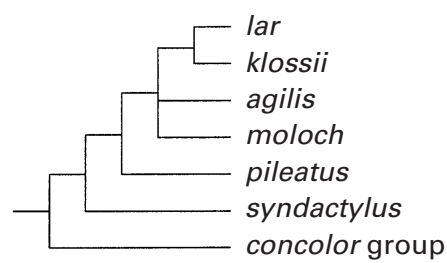

$\mathrm{H}$

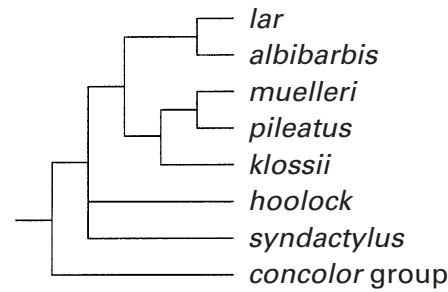

$J$

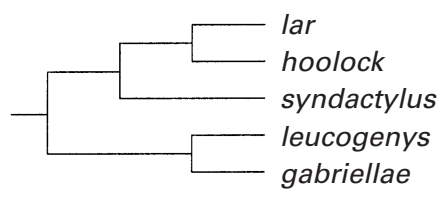

Fig. 6. Published representations of the phylogenetic relationships among gibbon taxa. (A) Chivers (1977); (B) Creel \& Preuschoft (1984); (C) Garza \& Woodruff (1992); (D) Groves (1972); (E) Haimoff et al. (1982); (F) Hayashi et al. (1995); (G) Purvis (1995); (H) Zhang (1997); (I) Zehr (1999); (J) Roos \& Geissmann (2001).

hypothesis that this non-duetting species has evolved from a duetting one. It would be even more impressive if a male $H$. moloch was producing a duet with a female $H$. lar, but such an example was not observed.

The arguments presented in this study suggest that $H$. moloch and $H$. klossii have secondarily abandoned duetting behaviour, and that the common ancestor of all recent hylobatids did produce duet songs. Only subsequently did the duet contributions of each sex become increasingly independent (stages 2a-5a in Fig. 7). This appears to be the first time that a non-duetting animal can be shown to be derived from a duetting form. This process is 


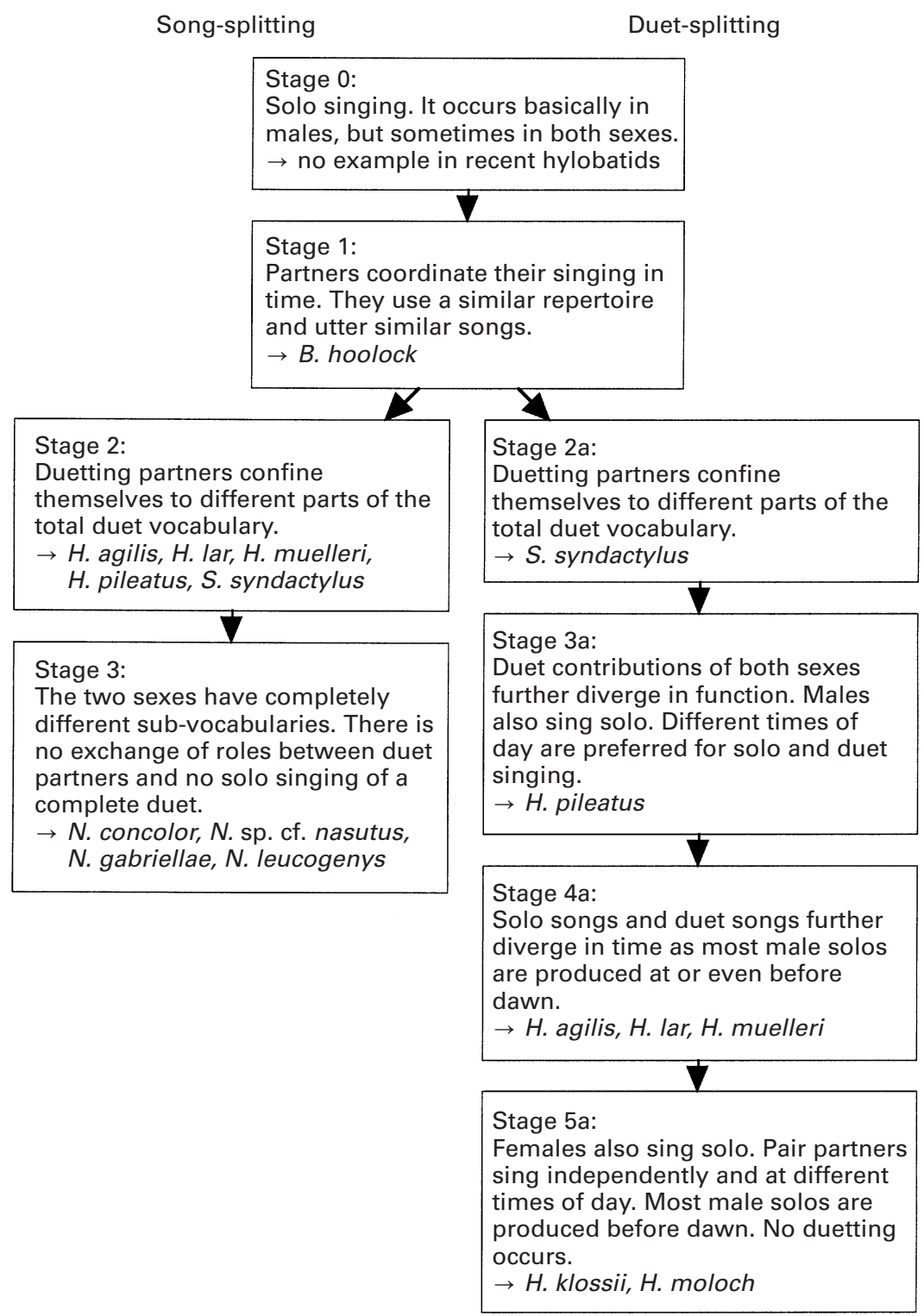

Fig. 7. Gibbon species arranged according to the song-splitting hypothesis and the duet-splitting hypothesis. See text for explanation.

tentatively called "duet-splitting", in analogy to the term song-splitting of Wickler and Seibt (1982), and is summarised in Fig. 7.

If mated females of $H$. muelleri do occasionally produce solo songs, as the currently available evidence appears to indicate (see above), this would represent an intermediate strategy between mated females which sing duet song bouts only and mated females which sing solo song bouts only. As a result, H. muelleri would occupy an additional intermediate stage between stages $4 \mathrm{a}$ and $5 \mathrm{a}$ in Fig. 7.

Of course, it would be interesting to know which evolutionary constraints may have favoured the occurrence of duet-splitting. One obvious approach to this problem is to scan all gibbon taxa for other characteristics shared by the non-duetting species but absent in duetting gibbons, or vice-versa. Aspects from ecology, geography and ethology of the various species were taken into consideration. As a result, it appeared that the non-duetting gibbons are unique in having no common border with other gibbon species. Whereas H. moloch is restricted to the western half of Java, and $H$. klossii occurs only on the small Mentawai islands, all duetting gibbon species are in contact with at least one other species, and all presently occupy larger areas of distribution than both non-duetting species (Chivers, 1977; Chivers \& Gittins, 1978; Groves, 1972; Marshall \& Sugardjito, 


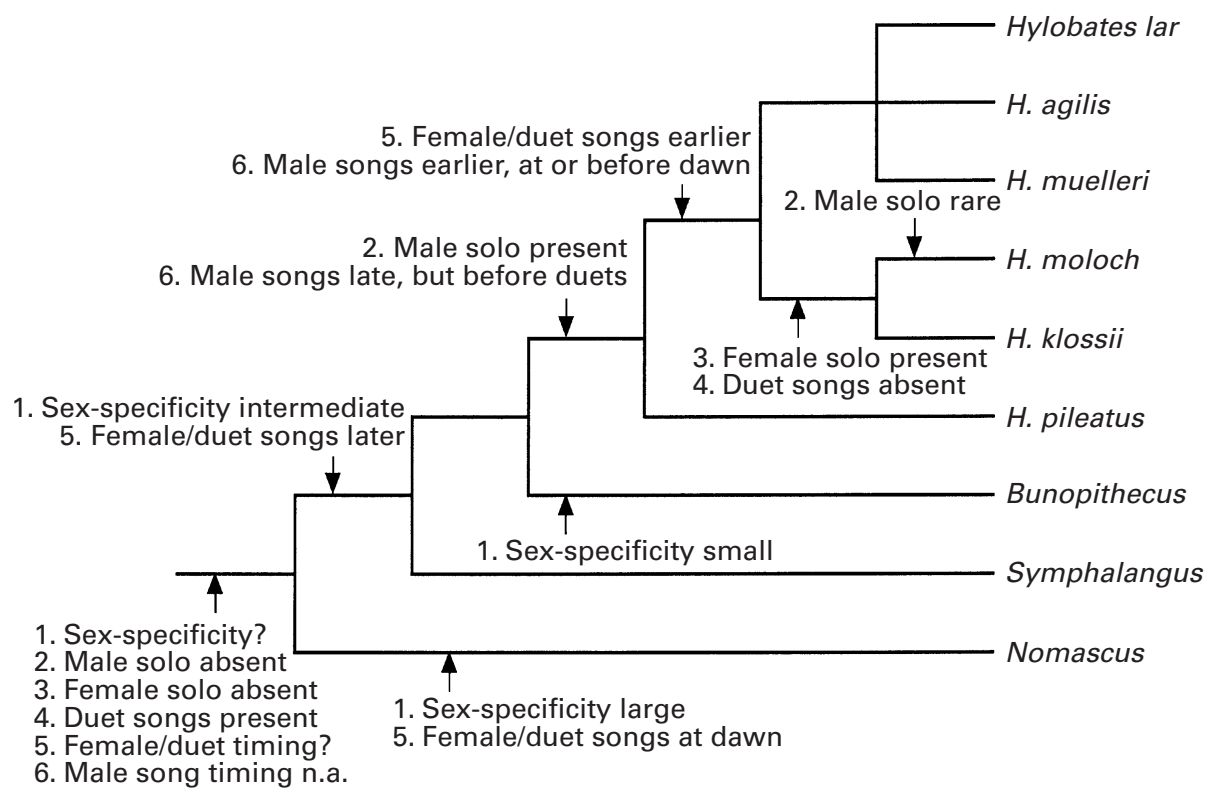

Fig. 8. Tracing the vocal character states on a hypothetical gibbon phylogeny (character state numbers as in Table 4). In this example, the tree proposed by Haimoff et al. (1982) was used, except that a sister taxon relationship was assumed for $H$. klossii and $H$. moloch, as explained in the text. Character 6 ("Male song timing") is not applicable ("n.a.") to Nomascus, Bunopithecus and Symphalangus, because mated males do not usually sing solo songs in these taxa.

1986). How might the benefits of duetting have diminished as a consequence of isolation?

It appears reasonable to assume that the acoustic differences between gibbon species evolved as a consequence of selection against hybridisation (Marshall \& Marshall, 1976; Mitani, 1987 a), but a causal relationship between speciation and duetting is unknown, so far. It has repeatedly been speculated on how traits that act as intrinsic barriers to inbreeding might be affected by the number of related species. Organisms released from the competitive pressure of related species could become less tightly adapted to a particular situation. It has been observed that songs of birds and crickets living on islands or in areas which are isolated from related species are less complex and less stereotyped (Catchpole \& Slater, 1995; Otte, 1989). Song simplicity of isolated species may result from the lack of need for complexity as a species marker where there are few other species (Catchpole \& Slater, 1995). Apparently, isolation can lead to the loss of signal elements and a return to simpler song types in birds and crickets. If isolation can lead to simpler song types and if solo singing is a simpler song type than duet singing, isolation could have reduced the necessity to produce complex composite signals by mated gibbon pairs and have freed males and females to sing independently. This purely speculative hypothesis appears plausible considering that there has already been some selection pressure acting on males and females to sing at different times of the day in some of the duetting species, as shown above.

\section{(3) Phylogenetic implications}

The position of $H$. moloch and $H$. klossii together at the same stage of duet-splitting suggests a synapomorphic character state. Because both species are isolated, the differences in their songs from those of other gibbons may result from convergence rather than common ancestry. Both species share a number of probably derived vocal character states, such as the presence of female solo song bouts, the absence of duet song bouts and the temporal separation of male and female singing. Because at least (the first) two of these character states are unique among gibbons, it appears more likely that they represent synapomorphies. I suspect that the two species are more closely related to each other than to other gibbons, in contrast to the various arrangements shown in previously published phylogenetic trees (Fig. 6). In Fig. 8, the vocal character states of the present study are traced on a hypothetical gibbon phylogeny. In this example, the tree proposed by Haimoff et al. (1982) was used, except that $H$. klossii was moved to a sister taxon position to $H$. moloch. Using the vocal characters of the present study, any other published hylobatid tree that includes these two species would 
be two steps shorter if $H$. klossii were recognised as a sister taxon of $H$. moloch.

Among recent gibbons, B. hoolock occupies the most primitive stage of song-splitting (Fig. 5), because males and females typically use the same repertoire of note types. If the song-splitting hypothesis is correct in identifying this as a primitive character state, derived stages of song-splitting would have evolved more than once unless $B$. hoolock occupied the most basal position in the phylogenetic tree. Most previously published trees shown in Fig. 6 , however, place either $S$. syndactylus, crested gibbons (concolor group) or both in that position, not $B$. hoolock (but see Zehr, 1999, and Fig. 6I). The results of the present study suggest that $B$. hoolock could be one of the candidates for the earliest split-off from the main stem of the gibbon radiation. Because only one variable of the present study (i.e. sex-specificity of the repertoire) supports that arrangement, this is a highly tentative conclusion which should be confirmed with a larger data set. It is important to keep in mind, however, that the main components of the gibbon phylogeny (i.e. the dichotomies among the four subgenera) are still not reliably resolved. The order of the generic splits has, so far, resisted conclusive analysis by molecular methods (Hall, Jones \& Wood, 1998; Hayashi et al., 1995; Zehr, 1999; Zhang, 1997; but see Roos \& Geissmann, 2001), and no two of the available molecular trees are alike. When more reliable and more complete phylogenetic trees are available, it will be possible to reconstruct the evolution of gibbon singing and duetting behaviour in much more detail.

\section{GONGLUSIONS}

Long and complex song bouts have been described for all gibbon species. Comparison of their singing behaviour supports the following conclusions concerning the evolution of gibbon songs:

(1) The recent hylobatids represent a monophyletic group, whose common ancestor produced duet songs, although not all recent species are known to do so.

(2) Duet songs of recent gibbon species are likely to have evolved according to the song-splitting theory: gibbon duets probably evolved from a song which was common to both sexes and which only later became separated into male-specific and female-specific parts.

(3) In the evolution of gibbon songs, a process tentatively called "duet-splitting" is suggested to have led secondarily from a duetting species to a non-duetting species, in that the contributions of the pair partners split into temporally segregated solo songs.

(4) The final stage of the duet-splitting process is represented by two species, $H$. klossii and $H$. moloch, which probably represent a monophyletic group.

(5) The complete segregation of male and female singing may have been facilitated by isolation from other gibbon species (island distribution).

\section{AGKNOWLEDGEMENTS}

I wish to thank the officials and staff members of the numerous zoos and the private gibbon holders for permission to study the animals in their care and for useful information about the animals' previous history. Additional tape-recordings used in the present study were kindly made available by Dr Lan Daoying, Dr Vincent Nijman, Dr M. Schwarz, and Dr R. R. Tenaza. I am particularly grateful to Prof. R. D. Martin, Prof. E. Zimmermann, Robert Dallmann and two anonymous reviewers for reading and commenting on earlier versions of this manuscript. This study was supported by the A. H. Schultz Foundation, the Messerli Foundation and by a special Research Grant donated by Dr A. and Mrs. E. Sigg.

\section{REFERENGES}

Adler, H. J. (1991). The crested gibbon, Hylobates (Nomascus) concolor Harlan, 1826, in the Nam Cat Tien Reserve, southern Vietnam. Primate Report 29, 59-64.

Brockelman, W. Y. \& Gittins, S. P. (1984). Natural hybridization in the Hylobates lar species group: Implications for speciation in gibbons. In The Lesser Apes. Evolutionary and Behavioural Biology (eds. H. Preuschoft, D. J. Chivers, W. Y. Brockelman and N. Creel), pp. 498-532. Edinburgh University Press, Edinburgh.

Brockelman, W. Y. \& Sahilling, D. (1984). Inheritance of stereotyped gibbon calls. Nature 312, 634-636.

Brockelman, W. Y. \& Srikosamatara, S. (1984). Maintenance and evolution of social structure in gibbons. In The Lesser Apes. Evolutionary and Behavioural Biology (eds. H. Preuschoft, D. J. Chivers, W. Y. Brockelman and N. Creel), pp. 298-323. Edinburgh University Press, Edinburgh.

Caldecott, J. O. \& Haimoff, E. H. (1983). Female solo singing by a wild lar gibbon in peninsular Malaysia. Malayan Nature fournal 36, 167-173.

Catchpole, C. K. \& Slater, P. J. B. (1995). Bird song: Biological themes and variations. Cambridge University Press, Cambridge, U.K.

Chivers, D. J. (1974). The Siamang in Malaya - A Field Study of a Primate in Tropical Rain Forest (Contributions to Primatology Vol. 4), Karger, Basel and New York.

Chivers, D. J. (1976). Communication within and between family groups of siamang (Symphalangus syndactylus). Behaviour 57, 116-135.

Chivers, D. J. (1977). The lesser apes. In Primate Conservation 
(eds. Prince Rainier III of Monaco and G. H. Bourne), pp. 539-598. Academic Press, New York.

Chivers, D. J. (1978). The gibbons of peninsular Malaysia. Malayan Nature Fournal 30, 565-591.

Chivers, D. J. (1984). Gibbons. In The Encyclopedia of Mammals, Vol. 1 (ed. D. MacDonald), pp. 415-419. Allen and Unwin, London.

Chivers, D. J. \& Gittins, S. P. (1978). Diagnostic features of gibbon species. International Zoo Tearbook 18, 157-164.

Choudhury, A. (1989). Vocalization in hoolock gibbon (Hylobates hoolock). Primate Report 25, 53-54.

Cowlishaw, G. (1992). Song function in gibbons. Behaviour 121, 131-153.

Creel, N. \& Preuschoft, H. (1984). Systematics of the lesser apes: A quantitative taxonomic analysis of craniometric and other variables. In The Lesser Apes. Evolutionary and Behavioural Biology (eds. H. Preuschoft, D. J. Chivers, W. Y. Brockelman and N. Creel), pp. 562-613. Edinburgh University Press, Edinburgh.

Dallmann, R. \& Geissmann, T. (2001). Individuality in the female songs of wild silvery gibbons (Hylobates moloch) on Java, Indonesia. Contributions to Zoology 70, 41-50.

Dallmann, R., \& Geissmann, T. (in press). Different levels of variability in the female song of wild silvery gibbons (Hylobates moloch). Behaviour.

Deputte, B. L. (1982). Duetting in male and female songs of the white-cheeked gibbon (Hylobates concolor leucogenys). In Primate communication (eds. S. T. Snowdon, C. H. Brown and M. R. Petersen), pp. 67-93. Cambridge University Press, Cambridge.

Farabaugh, S. M. (1982). The ecological and social significance of duetting. In Acoustic Communication in Birds (eds. D. E. Kroodsma, E. H. Miller and H. Ouellet), pp. 85-124. Academic Press, New York and London.

Feeroz, M. M. \& Islam, M. A. (1992). Ecology and behaviour of hoolock gibbons of Bangladesh, MARC (Multidisciplinary Action Research Centre), Dhaka, Bangladesh.

Garza, J. C. \& Woodruff, D. S. (1992). A phylogenetic study of the gibbons (Hylobates) using DNA obtained non-invasively from hair. Molecular Phylogenetics and Evolution 1, 202-210.

Geissmann, T. (1983). Female capped gibbon (Hylobates pileatus Gray 1891) sings male song. Fournal of Human Evolution 12, 667-671.

Geissmann, T. (1984). Inheritance of song parameters in the gibbon song, analyzed in 2 hybrid gibbons (Hylobates pileatus x H. lar). Folia Primatologica 42, 216-235.

Geissmann, T. (1993). Evolution of Communication in Gibbons (Hylobatidae). Ph.D. thesis, Anthropological Institute, Philosoph. Faculty II, Zürich University, Switzerland.

Geissmann, T. (1995a). Gibbon systematics and species identification. International Zoo News 42, 467-501.

Geissmann, T. $(1995 b)$. The yellow-cheeked gibbon (Hylobates gabriellae) in Nam Bai Cat Tien (southern Vietnam) revisited. Primates 36, 447-455.

Geissmann, T. (1997). New sounds from the crested gibbons (Hylobates concolor group): First results of a systematic revision. In Verhandlungen der Deutschen Zoologischen Gesellschaft: Kurzpublikationen - Short Communications, 90. Fahresversammlung 1997 in Mainz (ed. D. Zissler), p. 170. Gustav Fischer, Stuttgart.

Geissmann, T. (1999). Duet songs of the siamang, Hylobates syndactylus: II. Testing the pair-bonding hypothesis during a partner exchange. Behaviour 136, 1005-1039.
Geissmann, T. (2000a). Duet songs of the siamang, Hylobates syndactylus: I. Structure and organisation. Primate Report 56, 33-60.

Geissmann, T. $(2000 b)$. Gibbon songs and human music in an evolutionary perspective. In The Origins of Music (eds. N. Wallin, B. Merker and S. Brown), pp. 103-123. MIT Press, Cambridge, Massachusetts.

Geissmann, T. (in press). Taxonomy and evolution of gibbons. Evolutionary Anthropology (Supplement).

Geissmann, T. \& Nijman, V. (2000). Do male silvery gibbons have anything to say? - Haben männliche Silbergibbons etwas zu sagen? Folia Primatologica 71, 225 (Abstract only).

Geissmann, T., Nguyen Xuan Dang, Lormée, N. \& Momberg, F. (2000) Vietnam Primate Conservation Status Review 2000 - Part 1: Gibbons. Fauna \& Flora International, Indochina Programme, Hanoi.

Geissmann, T. \& Orgeldinger, M. (2000). The relationship between duet songs and pair bonds in siamangs, Hylobates syndactylus. Animal Behaviour 60, 805-809.

Gittins, S. P. (1978). Hark! The beautiful song of the gibbon. New Scientist 80, 832-834.

Gitrins, S. P. (1984a). Territorial advertisement and defence in gibbons. In The Lesser Apes. Evolutionary and BehaviouraI Biology (eds. H. Preuschoft, D. J. Chivers, W. Y. Brockelman and N. Creel), pp. 420-424. Edinburgh University Press, Edinburgh.

Gitrins, S. P. $(1984 b)$. The vocal repertoire and song of the agile gibbon. In The Lesser Apes. Evolutionary and Behavioural Biology (eds. H. Preuschoft, D. J. Chivers, W. Y. Brockelman and N. Creel), pp. 354-375. Edinburgh University Press, Edinburgh.

Gittins, S. P. \& Raemaekers, J. J. (1980). Siamang, lar and agile gibbons. In Malayan Forest Primates - Ten Years' Study in Tropical Rain Forest (ed. D. J. Chivers), pp. 63-105. Plenum Press, New York.

Gittins, S. P. \& Tilson, R. L. (1984). Notes on the ecology and behaviour of the hoolock gibbon. In The Lesser Apes. Evolutionary and Behavioural Biology (eds. H. Preuschoft, D. J. Chivers, W. Y. Brockelman and N. Creel), pp. 258-266. Edinburgh University Press, Edinburgh.

Groves, C. P. (1972). Systematics and phylogeny of gibbons. In Gibbon and Siamang, Vol. 1 (ed. D. M. Rumbaugh), pp. 1-89. Karger, Basel and New York.

Groves, C. P. (1984). A new look at the taxonomy and phylogeny of the gibbons. In The Lesser Apes. Evolutionary and Behavioural Biology (eds. H. Preuschoft, D. J. Chivers, W. Y. Brockelman and N. Creel), pp. 542-561. Edinburgh University Press, Edinburgh.

Haimoff, E. H. (1983). Gibbon Songs: An Acoustical, Organizational, and Behavioural Analysis. PhD. diss., University of Cambridge.

Haimoff, E. H. (1984a). Acoustic and organizational features of gibbon songs. In The Lesser Apes. Evolutionary and Behavioural Biology (eds. H. Preuschoft, D. J. Chivers, W. Y. Brockelman and N. Creel), pp. 333-353. Edinburgh University Press, Edinburgh.

Haimoff, E. H. (1984b). The organization of song in the agile gibbon (Hylobates agilis). Folia Primatologica 42, 42-61.

Haimoff, E. H. (1985a). Some observations on the singing behaviour of the hoolock gibbon (Hylobates hoolock). Fournal of the Bombay Natural History Society 82, 1-12.

Haimoff, E. H. (1985b). The organization of song in Müller's gibbon (Hylobates muelleri). International Fournal of Primatology $\mathbf{6}$, 173-192. 
Haimoff, E. H. (1986). Convergence in the duetting of monogamous Old World primates. Fournal of Human Evolution 15, 51-59.

Haimoff, E. H., Ghivers, D. J., Gittins, S. P. \& Whitten, A. J. (1982). A phylogeny of gibbons (Hylobates spp.) based on morphological and behavioural characters. Folia Primatologica 39, 213-237.

Haimoff, E. H. \& Gittins, S. P. (1985). Individuality in the songs of wild agile gibbons (Hylobates agilis) of Peninsular Malaysia. American Fournal of Primatology 8, 239-247.

Haimoff, E. H., Gittins, S. P., Whitten, A. J. \& Chivers, D. J. (1984). A phylogeny and classification of gibbons based on morphology and ethology. In The Lesser Apes. Evolutionary and Behavioural Biology (eds. H. Preuschoft, D. J. Chivers, W. Y. Brockelman and N. Creel), pp. 614-632. Edinburgh University Press, Edinburgh.

Haimoff, E. H. \& Tilson, R. L. (1985). Individuality in the female songs of wild Kloss' gibbons (Hylobates klossii) on Siberut Island, Indonesia. Folia Primatologica 44, 129-137.

Haimoff, E. H., Yang, X.-J., He, S.-J. \& Chen, N. (1987). Preliminary observations of wild black-crested gibbons (Hylobates concolor concolor) in Yunnan Province, People's Republic of China. Primates 28, 319-335.

Hall, L. M., Jones, D. S. \& Wood, B. A. (1998). Evolution of the gibbon subgenera inferred from cytochrome $b$ DNA sequence data. Molecular Phylogenetics and Evolution 10, 281-286.

Hayashi, S., Hayasaka, K., Takenaka, O. \& Horai, S. (1995). Molecular phylogeny of gibbons inferred from mitochondrial DNA sequences: Preliminary report. Fournal of Molecular Evolution 41, 359-365.

Hu, Y., Xu, H. \& YANG, D. (1989). [The studies on ecology in Hylobates leucogenys]. Zoological Research $\mathbf{1 0}$ (Supplement), 61-67 (Chinese text, English summary).

JiAng, X. \& WANG, Y. (1997). [The singing ecology and behavior of black crested gibbons]. Acta Anthropologica Sinica 16, 293-301 (Chinese text, English summary).

Kappeler, M. (1981). The Javan Silvery Gibbon (Hylobates lar moloch). Ph.D. thesis, Philisophisch-Naturwissenschaftliche Fakultät, Universität Basel, Switzerland.

KAPPELER, M. (1984). Vocal bouts and territorial maintenance in the moloch gibbon. In The Lesser Apes. Evolutionary and Behavioural Biology (eds. H. Preuschoft, D. J. Chivers, W. Y. Brockelman and N. Creel), pp. 376-389. Edinburgh University Press, Edinburgh.

LAN, D.-Y. (1993). Feeding and vocal behaviours of black gibbons (Hylobates concolor) in Yunnan: A preliminary study. Folia Primatologica 60, 94-105.

Leighton, D. R. (1987). Gibbons: Territoriality and monogamy. In Primate Societies (eds. B. B. Smuts, D. L. Cheney, R. M. Seyfarth, R. W. Wrangham and T. T. Struhsaker), pp. 135-145. University of Chicago Press, Chicago and London.

MacKinnon, J. (1974). The behaviour and ecology of wild orang-utan (Pongo pygmaeus). Animal Behaviour 22, 3-74, +5 plates.

Marler, P. \& Tenaza, R. (1977). Signaling behavior of apes with special reference to vocalization. In How Animals Communicate (ed. T. A. Sebeok), pp. 965-1033. Indiana University Press, Bloomington and London.

Marshall, J. T. (1981). The agile gibbon in south Thailand. Natural History Bulletin of the Siam Society 29, 129-136.

Marshall, J. T. \& Marshall, E. R. (1976). Gibbons and their territorial songs. Science 193, 235-237.
Marshall, J. T. \& Marshall, E. R. (1978). The Gibbons: Songs of All Species Recorded in their Natural Forest Habitat. Phonograph disc (eds. J. W. Hardy and G. K. Hardy). ARA-Records, 1615 NW 14th Ave., Gainesville, FL 32605, USA.

Marshall, J. T., Ross, B. A. \& Chantharojvong, S. (1972). The species of gibbons in Thailand. Fournal of Mammalogy 53, 479-486.

Marshall, J. T. \& Sugardjito, J. (1986). Gibbon systematics. In Comparative Primate Biology, Vol. 1: Systematics, Evolution, and Anatomy (eds. D. R. Swindler and J. Erwin), pp. 137-185. Alan R. Liss, New York.

Marshall, J. T., Sugardjito, J. \& Markaya, M. (1984). Gibbons of the lar group: Relationships based on voice. In The Lesser Apes. Evolutionary and Behavioural Biology (eds. H. Preuschoft, D. J. Chivers, W. Y. Brockelman and N. Creel), pp. 562-613. Edinburgh University Press, Edinburgh.

Mather, R. (1992). A field study of hybrid gibbons in central Kalimantan, Indonesia, Ph.D. thesis, Sub. Dept. of Veterinary Anatomy. Cambridge University, U.K.

Mitani, J. C. (1984). The behavioral regulation of monogamy in gibbons (Hylobates muelleri). Behavioral Ecology and Sociobiology 5, 225-229.

Mitani, J. C. (1985a). Gibbon song duets and intergroup spacing. Behaviour 92, 59-96.

Mitani, J. C. $(1985 b)$. Location-specific responses of gibbons (Hylobates muelleri) to male songs. Zeitschrift für Tierpsychologie 70, 219-224.

Mrtani, J. C. $(1985 c)$. Responses of gibbons (Hylobates muelleri) to self, neighbor, and stranger song duets. International fournal of Primatology 6, 193-200.

Mitani, J. C. $(1987 a)$. Species discrimination of male song in gibbons. American Fournal of Primatology 13, 413-423.

Mitani, J. C. $(1987 b)$. Territoriality and monogamy among agile gibbons (Hylobates agilis). Behavioral Ecology and Sociobiology 20, 265-269.

Mitani, J. C. (1988). Male gibbon (Hylobates agilis) singing behavior: Natural history, song variations and function. Ethology 79, 177-194.

Mitani, J. C. (1990). Experimental field studies of Asian ape social systems. International fournal of Primatology 11, 103-126.

Mitani, J. C. \& Marler, P. (1989). A phonological analysis of male gibbon singing behavior. Behaviour 109, 20-45.

Отте, D. (1989). Speciation in crickets. In Speciation and its consequences (eds. D. Otte and J. A. Endler), pp. 482-526. Sinauer Associates, Sunderland, Mass.

Purvis, A. (1995). A composite estimate of primate phylogeny. Philosophical Transactions of the Royal Society of London B 348, 405-421.

Raemaekers, J.J. \& Raemaekers, P. M. (1984a). The ooaa duet of the gibbon (Hylobates lar). A group call which triggers other groups to respond in kind. Folia Primatologica 42, 209-215.

Raemaekers, J.J. \& Raemaekers, P. M. (1984b). Vocal interactions between two male gibbons, Hylobates lar. Natural History Bulletin of the Siam Society 32, 95-106.

Raemaekers, J.J. \& Raemaekers, P. M. (1985a). Field playback of loud calls to gibbons (Hylobates lar): territorial, sex-specific and species-specific responses. Animal Behaviour 33, 481-493.

Raemaekers, P. M. \& Raemaekers, J. J. (1985b). Long-range vocal interactions between groups of gibbons (Hylobates lar). Behaviour 95, 26-44. 
Raemaekers, J. J., Raemaekers, P. M. \& Haimoff, E. H. (1984). Loud calls of the gibbon (Hylobates lar): Repertoire, organization and context. Behaviour 91, 146-189.

Roos, C. \& Geissmann, T. (2001). Molecular phylogeny of the major hylobatid divisions. Molecular Phylogenetics and Evolution 19, 486-494.

Sahilling, D. (1984). Song bouts and duetting in the concolor gibbon. In The Lesser Apes. Evolutionary and Behavioural Biology (eds. H. Preuschoft, D. J. Chivers, W. Y. Brockelman and N. Creel), pp. 390-403. Edinburgh University Press, Edinburgh.

Schmidt, R., Radin, J. \& Brodie, J. (1989). MacRecorder User's Guide. Farallon Computing, Inc., Emeryville.

Seibt, U. \& Wigkler, W. (1982). Rolle des Duettierens im Leben der Vögel. In Max-Planck-Gesellschaft Fahrbuch 1982. Verlag Vandenhoeck and Ruprecht, Göttingen, pp. 351-352.

Srikosamatara, S. (1980). Ecology and Behaviour of the Pileated Gibbon (Hylobates pileatus) in Khao Soi Dao Wildlife Sanctuary, Thailand. Unpublished M.Sc. Thesis, Faculty of Graduate Studies, Mahidol University, Bangkok.

SRikosamatara, S. (1982). Imitation of vocal duet by a widow of the pileated gibbon (Hylobates pileatus) in Southeast Thailand. International Fournal of Primatology 3, 336 (Abstract only).

Srikosamatara, S. \& Brockelman, W. Y. (1983). Patterns of territorial vocalization in the pileated gibbon (Hylobates pileatus). In Perspectives in Primate Biology (ed. P. K. Seth), pp. 19-22. Today \& Tomorrow's Printers and Publishers, New Delhi.

Srikosamatara, S. \& Brogkelman, W. Y. (1987). Polygyny in a group of pileated gibbons via a familial route. International Fournal of Primatology 8, 389-393.

Tembrock, G. (1977). Tierstimmenforschung. Eine Einführung in die Bioakustik. Die Neue Brehm-Bücherei 250. A. Ziemsen Verlag, Wittenberg Lutherstadt.

Tenaza, R. R. (1976). Songs, choruses and countersinging among Kloss' gibbons (Hylobates klossi) in Siberut island, Indonesia. Zeitschrift für Tierpsychologie 40, 37-52.
Tenaza, R. R. (1985). Songs of hybrid gibbons (Hylobates lar x H. muelleri). American Fournal of Primatology 8, 249-253.

Thorpe, W. H. (1961). Bird-Song. The Biology of Vocal Communication and Expression in Birds. Cambridge monographs in experimental biology No. 12. University Press, Cambridge.

Thorpe, W. H. (1972). Duetting and antiphonal song in birds: Its extent and significance. Behaviour Supplement 18, i-xi, $1-197$.

Volz, W. (1904). Über die Verbreitung einiger anthropoider Affen in Sumatra. Biologisches Centralblatt 24(14), 475-476.

West, K. L. (1982). The Ecology and Behavior of the Siamang (Hylobates syndactylus) in Sumatera. M.Sc. thesis, University of California, Davis.

Whitten, A.J. (1980). The Kloss gibbon in Siberut rain forest. Ph.D. diss., Sub-department of Veterinary Anatomy, University of Cambridge.

Whitten, A. J. (1982). The ecology of singing in Kloss gibbons (Hylobates klossii) on Siberut Island, Indonesia. International Fournal of Primatology 3, 33-51.

Whitten, A. J. (1984). The trilling handicap in Kloss gibbons. In The Lesser Apes. Evolutionary and Behavioural Biology (eds. H. Preuschoft, D. J. Chivers, W. Y. Brockelman and N. Creel), pp. 416-419. Edinburgh University Press, Edinburgh.

Wigkler, W. (1974). Duette und Paarbindung bei Tieren. Mitteilungen der Max-Planck-Gesellschaft 1974, 237-252.

Wigkler, W. \& Seibt, U. (1980). Vocal dueting and the pair bond: II. Unisono dueting in the African forest weaver, Symplectes bicolor. Zeitschrift für Tierpsychologie 52, 217-226.

Wiakler, W. \& SEIBT, U. (1982). Song splitting in the evolution of dueting. Zeitschrift für Tierpsychologie 59, 127-140.

Zenr, S. M. (1999). A nuclear and mitochondrial phylogeny of the lesser apes (Primates, genus Hylobates). Ph.D. thesis, Harvard University, Cambridge, Massachusetts.

Zhang, Y. (1997). [Mitochondrial DNA sequence evolution and phylogenetic relationships of gibbons]. Acta Genetica Sinica 24, 231-237 (Chinese text, English summary). 